IRSH 62 (20I7), pp. 2 I 5-252 doi:10.10I7/S00208590I 7000177

(C) 2017 Internationaal Instituut voor Sociale Geschiedenis

\title{
Colonial State Formation Without Integration: Tax Capacity and Labour Regimes in Portuguese Mozambique (I 890s-I970s)*
}

\author{
KLEONIKI ALEXOPOULOU \\ Wageningen University $\&$ Research \\ Department of Social Sciences
}

PO Box 8130, 6700 EW Wageningen, The Netherlands

E-mail: kleoniki.alexopoulou@wur.nl

\author{
D Á C IL Ju IF \\ Wageningen University \& Research and Universidad Carlos III \\ de Madrid \\ Facultad de Ciencias Sociales y Jurídicas \\ Calle Madrid, I26, 28903 Getafe (Madrid), Spain
}

E-mail:djuif@clio.uc3m.es

\begin{abstract}
AвSTRACT: Samir Amin (1972) divided the African continent into three "macro-regions of colonial influence" with distinct socio-economic systems and labour practices: Africa of the colonial trade or peasant economy, Africa of the concession-owning companies, and Africa of the labour reserves. We argue that Mozambique encompassed all three different "macro-regions" in a single colony. We reconstruct government revenue (direct/indirect taxes) raised at a district level between 1930 and 1973 and find persisting differences in the "tax capacity" of the three regions throughout the colonial period.
\end{abstract}

\footnotetext{
* We would like to thank Ewout Frankema, Elise van Nederveen Meerkerk, Jutta Bolt, Pieter Woltjer, Kostadis Papaioannou, Christina Mumme, Carsten Burhop, Erik Green, Rachel Meyer, as well as three anonymous referees and the editorial board for their insightful comments. We also owe our gratitude to the archivists and librarians in Lisbon, Maputo, and Pretoria for their valuable advice and to Jessica M.C. Lima for her assistance; to the participants of the Workshop on "Colonialism, Growth and Development in the Southern Hemisphere, I800-2000" at Lund University (April 2015); as well as to the participants of the ERSA workshop on "The Fiscal History of Sub-Saharan Africa” at Stellenbosch University (May 2015) and of the Social Science History Association conference in Baltimore (November 201 5). We are grateful for the working paper version published by the African Economic History Network (AEHN) and for the financial support provided by the Netherlands Organization for Scientific Research (NWO) as part of the VIDI project "Is Poverty Destiny? Exploring Long-Term Changes in African Living Standards in Global Perspective”. The usual disclaimer applies.
} 
The tax systems, we claim, developed in response to existing local geographic and economic conditions, particularly to labour practices. Portuguese colonial rule adapted to and promoted labour practices such as migration and forced labour to maximize revenue. The extent to which the lack of integration played a role in the post-colonial state and fiscal failure should be studied further.

\section{INTRODUCTION}

Fiscal or tax capacity, defined as the ability of the state to collect revenue and invest in state-building, determines the scope for the state to provide public goods, which, in turn, has consequences for economic development and well-

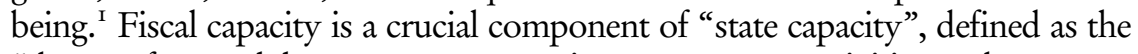
"degree of control that state agents exercise over persons, activities, and resources within their government's territorial jurisdiction". ${ }^{2}$ It is widely held that modern state and fiscal capacity are essentially shaped by historical developments. ${ }^{3}$

Many post-colonial states in Africa, including Mozambique, are often considered failed or fragile. ${ }^{4}$ Following colonialism, the legitimization of these independent African states is low and taxation is imposed by force rather than by consent. It is therefore crucial to study the historical origins of these states, the conditions under which they were formed, and the transformations they underwent. The development of fiscal systems was an important aspect of state formation in Africa by European colonial powers, as posited in the Berlin Act of I 88 5. Yet, imposing direct taxation in colonial times was a particularly costly undertaking, constrained by local geographic and economic conditions. Moreover, it occasionally resulted in unwelcome consequences, such as mass emigration and even armed resistance. Therefore, colonial powers usually limited their investments in fiscal capacity to the urban centres with strong European presence.

I. Besley and Persson view state capacity as the ability to effectively implement policies that foster economic growth, with fiscal and legal capacity being its principal components. Timothy Besley and Torsten Persson, "State Capacity, Conflict, and Development”, Econometrica, 78:I (2010), pp. I-34, 6 .

2. Doug McAdam, Sidney Tarrow, and Charles Tilly, Dynamics of Contention (Cambridge, 200I), p. 78.

3. Charles Tilly, Coercion, Capital and European States, AD 990-1990 (Oxford, 1990). Tilly holds that past wars in Europe created an incentive for the state to invest in institutions enabling revenue to be raised from the population. This theory was tested empirically by Mark Dincecco, James Fenske, and Massimiliano G. Onorato, "Is Africa Different? Historical Conflict and State Development", CSAE Working Paper WPS/2014-35 (2014).

4. Post-colonial Mozambique can be considered an example of state failure with historical roots. Persistent economic and political fractionalization created a fertile ground for internal conflict. After the Mozambican War of Independence (1964-1974), civil war dominated for fifteen years (1977-1992). See Paul Collier and Nicholas Sambanis (eds), Understanding Civil War: Evidence and Analysis, Volume I: Africa (Washington, 2005), p. I6r. 
As recent scholarship has shown, there was also diversity in tax capacity across African colonies, mainly shaped by local geographic and commercial conditions. ${ }^{5}$ Two recent studies argue that the significant differences in fiscal capacity within contemporary sub-Saharan Africa have historical roots and are closely linked to colonial labour policies and practices. ${ }^{6}$

One way of unravelling these colonial roots is to follow Samir Amin's threefold categorization of "macro-regions of colonial influence": I) "Africa of the colonial trade economy", areas with a long tradition of international trade, where indigenous peasants produced cash crops for the European market; 2) "Africa of the concession-owning companies", where colonial governments granted large land concessions and mineral rights to private companies, which partly took over the administration and tax collection in their territory; 3 ) "Africa of the labour reserves", territories in southern Africa where the good climate and geography favoured large European settlements, and a large labour pool was readily available for the surrounding mines and settler farms. ${ }^{7}$ In the latter group of countries, colonial policy backed the interests of industry and settlers with regard to pushing the indigenous population into wage labour by land expropriations and by raising hut or poll taxes. In panel and cluster regression analyses, Mkandawire as well as Feger and Asafu-Adjaye find that the labour reserve economies are still characterized by the highest tax levies, followed by cash-croptrade and concession economies. In the labour reserves, they argue, the interest in a booming mining and farming sector - as well as the intention of many Europeans to settle long term - motivated the colonial administration to be more interventionist, whereas in cash-crop and concession economies the involvement of the state in developing solid institutions was kept to a minimum.

Nonetheless, not all African countries fit Amin's categorization. For instance, although Amin placed Mozambique in the category of labour reserves, one could also argue that the Portuguese colony was not only a labour pool, and that it encompassed all three economic zones. ${ }^{8}$ The north

5. For example, Ewout Frankema and Marlous van Waijenburg, "Metropolitan Blueprints of Colonial Taxation? Lessons from Fiscal Capacity Building in British and French Africa, c. I 880-1940", Journal of African History, 55:3 (2014), pp. 371-400. They claim that "the formation of the fiscal state was primarily determined by the opportunities and constraints set by local commercial and environmental conditions". This view goes against some of the earlier African economic history literature, which emphasized the role of colonial identity in shaping institutions in Africa.

6. Thandika Mkandawire, "On Tax Efforts and Colonial Heritage in Africa", Journal of Development Studies, 46: 10 (2010), pp. 1647-I669, as well as Thuto Feger and John Asafu-Adjaye, "Tax Effort Performance in Sub-Sahara Africa and the Role of Colonialism”, Economic Modelling, 38 (20I4), pp. I63-I74.

7. Samir Amin, "Underdevelopment and Dependence in Black Africa: Origins and Contemporary Forms", Journal of Modern African Studies, I0:4 (1972), pp. 503-524.

8. On the persistence of three distinct geographic zones in Mozambique from the perspective of agricultural production. See Merle L. Bowen, The State Against the Peasantry: Rural Struggles in Colonial and Postcolonial Mozambique (Charlottesville, VA, 2000), p. 32. 
was a largely peasant-based economy, the central region was exploited by concession companies and was dominated by forced labour, and the south functioned as a labour reserve for the mines of South Africa and Southern Rhodesia (now Zimbabwe). We argue that the different labour regimes in the north, centre, and south resulted in an unintegrated fiscal state. The south developed much stronger state capacity than the north and the centre. First, indigenous labour migration to the mines became a rich source of tax revenue. Second, this became the region where most Europeans settled, and where Lourenço Marques (now Maputo), the capital of Mozambique, has been located since i 898. The peasant-based north, where large parts of the population were subsistence farmers, became the region with the weakest tax capacity. The centre, outsourced to concessionary companies, was not particularly effective in collecting taxes either, but developed a strong reliance on forced labour that allowed companies and state to save expenses on wages and combat labour scarcity.

Unlike Feger and Asafu-Adjaye and Mkandawire, who do not provide tax data for the colonial period and merely assume the temporal stability of colonial labour practices, ${ }^{9}$ we provide empirical evidence on taxation and labour practices in Mozambique from the early colonial period until independence, and show a strong persistence of regional differences. Focusing on a single colony has the advantage that we can abstract from the metropolitan identity as a source of variation and shift our attention to the interaction between local conditions and fiscal capacity. We add the case of a Portuguese territory to the literature on colonial fiscal development in Africa that has mostly excluded Lusitanian dominions. ${ }^{\circ}$ The spending side, which could also be considered an important aspect of fiscal capacity, is outside the scope of this paper.

For our quantitative analysis, we reconstruct real tax revenue per capita and the tax composition (direct/indirect taxes) of the three regions

9. Mkandawire, "On Tax Efforts", and Feger and Asafu-Adjaye, "Tax Effort Performance", compare post-colonial African tax systems from a "colonial legacies" perspective. They identify different kinds of colonial labour regimes (atemporal) as the root cause of differences in fiscal capacity from the 1980 s to 2000 s, but they do not provide data for the colonial period. This line of literature has been criticized by Gareth Austin for "compressing history". See Gareth Austin, "The 'Reversal of Fortune' Thesis and the Compression of History: Perspectives from African and Comparative Economic History", Journal of International Development, 20 (2008), pp. 996-1027.

I0. For instance, Ewout Frankema, "Raising Revenue in the British Empire, I 870-1940: How 'Extractive' were Colonial Taxes?”, Journal of Global History, 5:3 (2010), pp. 447-477; idem, "Colonial Taxation and Government Spending in British Africa, I 880-1940: Maximizing Revenue or Minimizing Effort?", Explorations in Economic History, 48:I (20I I), pp. I36-I49; Leigh A. Gardner, Taxing Colonial Africa: The Political Economy of British Imperialism (Oxford, 201 2); Frankema and Van Waijenburg, "Metropolitan Blueprints". 
(nine districts in total) of Mozambique for much of the colonial period (1930-1973). ${ }^{\text {I }}$ We then focus primarily on direct and particularly on indigenous taxation (imposto de palhota / imposto indigena), consisting of hut or per capita taxes imposed by the Portuguese state on the indigenous population at fixed rates. ${ }^{\mathrm{I} 2}$ Direct taxation is generally more strongly associated with state capacity than indirect taxation, which is related more to the availability of an easy source of revenue such as trade. ${ }^{13}$ The data on revenue was collected from the public finance statistics published in the colonial statistical yearbooks and accounts of Mozambique, at the Instituto Nacional d'Estatística (INE) in Lisbon. We retrieved information on the number of migrant workers and other demographic, geographic, and economic factors at a provincial level from the yearbooks, as well as from additional sources found at the Historical Archive of Mozambique and the Centre for African Studies at Universidade Eduardo Mondlane (UEM) in Maputo. ${ }^{I 4}$ For the qualitative part of the paper, we make use of colonial reports that shed light on taxation and labour practices, including chain migration to South Africa, coercive labour, and forced cropping. ${ }^{\text {Is }}$ We explain the lack of integration as a result of local conditions (including labour practices) and the rule of a relatively weak imperial power in economic terms. We also argue that the Portuguese colonial government not only failed to unify the fiscal system, it actually exacerbated these regional differences.

The paper is structured as follows: the first section presents an overview of fiscal systems in colonial Africa and in Mozambique specifically. The second section gives a historical overview, including qualitative and quantitative evidence of the distinct characteristics of the three zones of Mozambique that affected fiscal capacity-building in the colonial era. The third section is an empirical analysis of tax revenue, showing the differences

I I. The whole territory was transferred to the control of the Portuguese colonial government between 1929 and 1942. Previously, parts of it were under the complete control of concession companies.

I 2. Colonia de Moçambique, Legislação sobre Imposto Indigena (Lourenço Marques, I946).

I 3. Jeffrey Herbst, States and Power in Africa: Comparative Lessons in Authority and Control (Princeton, 2000). Consumption taxes, on the other hand, were insignificant in colonial Africa. I4. We are aware that colonial records can be biased in certain aspects, for example in the profiling of Africans as unindustrious. However, if population and tax records are biased, we can expect the bias to be either equally distributed among districts or undercounting to be more prevalent in the north, where state capacity was lowest and administrative control weakest. This bias would then actually strengthen our main argument concerning fiscal inequality between the three regions.

i s. Portuguese Mozambique relied longer than other colonies on forced labour, and sent large numbers of migrant labourers to the mines in South Africa and Southern Rhodesia. As Penvenne stated, the history of Mozambique is "largely the history of the international leasing of migrant labour outside the country and the national commandeering of forced labour within the country". Jeanne Penvenne, "Attitudes Toward Race and Work in Mozambique: Lourenço Marques, 1900-1974”, Boston University African Studies Center Working Papers I6 (I979), p. 2. 
in direct taxation and its determinants between the north, the centre, and the south. The fourth section explains why state formation took place without integration, and the final section concludes our paper.

\section{FISCAL CAPACITY-BUILDING IN COLONIAL AFRICA AND MOZAMBIQUE}

One of the most important aims of early colonial administrations in Africa was to introduce a system of tax collection. ${ }^{16}$ First, taxation was a prerequisite for "effective occupation" and legitimization of power, as defined in the Berlin Conference. ${ }^{17}$ Crawford Young analysed the development of the colonial African state based on the concepts of effective occupation and "hegemony imperative", which implied the establishment of hegemonic institutions (military outposts and networks of administrative centres). ${ }^{18}$ Second, the revenue imperative - also in place in the Portuguese empire implied that it was necessary for the colonial state to raise taxes in order to finance itself without putting a burden on the metropole. ${ }^{19}$ Third, imposing indigenous (direct) taxes was important to help "develop" the colony. It was supposed to have disciplinary power, by forcing the indigenous population to produce for the market or pushing it into wage labour, and it was also meant to contribute to the monetization of the economy. ${ }^{20}$

From the I870s to the I900s, indigenous taxes in Mozambique could be paid either in kind or in cash, depending on the area. However, the

I6. The colonial states and fiscal systems were more or less exogenously imposed, in contrast to the long-term evolution they underwent in Western Europe. Tilly, Coercion, Capital and European States.

17. In the General Act of the Berlin Conference, which can be seen as formalizing the Scramble for Africa, the principle of "effective occupation" stated that powers could acquire rights over colonial lands only if they possessed them or had treaties with local leaders, flew their flag there, and established an administration in the territory, governing it with a police force to keep order. Herbst, States and Power in Africa, pp. $7 \mathrm{I}-72$.

I8. Crawford Young, "The African Colonial State and its Political Legacy", in D. Rothschild and N. Chazan (eds), The Precarious Balance: State and Society in Africa (Boulder, CO [etc.], I988), pp. $25-66$.

19. Gardner, Taxing Colonial Africa, p. 40.

20. Already in the 1890 , the prominent regional commissioner of Mozambique, António Enes, had expressed his views on the crucial role of indigenous people as taxpayers and (either free or unfree) wage workers in the process of monetization and labour intensification, which would eventually contribute to agricultural development and the expansion of "civilization". See F. Ferreirinha, "Antonio Enes e o seu pensamento colonial", in Sociedade de Estudos da Colonia de Moçambique. Teses Apresentadas ao Io Congresso realizado de 8 a I3 de Septembro de 1947, vol. I (Lourenço Marques, 1947), p. 5. For Enes, this was the principal mission of colonialism. Taxation in the whole of colonial Africa has been perceived as a "discipline" and penal tool, in Foucauldian terms, that aimed at moralization and the stimulation of Africans' industriousness. See also Barbara Bush and Josephine Maltby, "Taxation in West Africa: Transforming the Colonial Subject into the 'Governable Person'”, Critical Perspectives on Accounting, I 5: I (2004), pp. 5-34. 
advantages of direct taxes paid in money - saving storage and transportation costs, and pushing the indigenes to the wage labour market - soon became undisputable and the system of indigenous cash taxes was gradually introduced in the whole territory in the early twentieth century. ${ }^{2 \mathrm{I}}$

The levying of indigenous taxes in Mozambique and the rest of Africa was, however, not an easy task and thus many colonial states relied on indirect taxes as much as possible. Overall, it has been claimed, colonial states in Africa were mostly "gatekeeper states", whose power was limited to controlling the borders and thus to collecting trade taxes. ${ }^{22}$ First, a complex state apparatus was needed in order to raise direct taxes, and putting it in place was costly, as it involved recruiting and training tax inspectors and investing in systems of control. Second, imposing hut and poll taxes often caused resistance, which was costly to subdue. Third, it could lead to undesirable mass emigration, often from underpopulated regions such as the central and southern zones of Mozambique. Fourth, many areas in Africa, such as the north of Mozambique, were not monetized, at least in early colonial times. Since indigenous peasants relied on subsistence farming, cash tax payments were difficult to collect. However, the Mozambique colony, where natural resources were scarce and trade volumes were relatively insignificant, had to rely to a much larger extent on direct taxation than many other colonies. For instance, the value of exports per capita in Mozambique was one third of Belgian Congo's in 1960, and less than half the value of per capita exports in Portuguese Angola. ${ }^{23}$ This seems to confirm the claim by Frankema and Van Waijenburg in their study on French and British Africa: "The highest direct tax shares were to be found in the least commercialized areas". ${ }^{24}$ More commercialized and coastal regions (controlled to a larger extent by the British) had higher levels of taxation but also a lower share of direct to total taxes.

Colonial states also relied on forced labour for building their infrastructure while saving public expenditures on wages. Van Waijenburg argues that forced labour functioned as an implied type of government tax

21. In the early years of the twentieth century, the governor of Lourenço Marques in Mozambique argued against the payment of taxes in kind. In his notes he highlighted, among other things, the transportation and storage costs derived from such transactions as well as the fluctuating prices and thus the questionable value of the exchangeable products. But most importantly, he emphasized the scarcity of labour in the area, caused by the fact that indigenous people did not need to pay taxes in money, so they did not need to work for companies to receive wages. Francisco Roque de Aguiar, Imposto de palhota: Distrito de Lourenço Marques (n.d.), pp. 75-76. Therefore, payment in kind constrained the effectiveness of colonial rule and hampered the economic development of the region.

22. Frederick Cooper, Africa Since 1940: The Past of the Present (Cambridge, 2002).

23. Brian R. Mitchell, International Historical Statistics: Africa and Asia (New York, 1982).

24. Frankema and Van Waijenburg, "Metropolitan Blueprints", p. 383. 
in French West Africa. She calculated the costs saved on wages through the use of forced labour as a proportion of total state revenue. ${ }^{25}$ Similarly, in Portuguese Mozambique, forced labour was used as a complement to direct taxes. Especially in areas that were not monetized and where labour was needed for plantations, the state and concession companies relied heavily on forced labour. Until i 962, various forms of forced labour were in place in Mozambique: coercive (compelido) and punitive (correcional) labour, domestic labour by women working in European households, and forced labour exile, for instance to the cocoa plantations in São Tomé. ${ }^{26}$ O'Laughlin notes that both men and women were pressured into variable periods of punitive labour (corvée) for non-criminal offences such as evading taxes or escaping from contract labour. ${ }^{27}$ Although the Portuguese colonies in Africa were not the only ones to rely on forced labour, they did so for much longer than the French and British, despite international pressure. Portugal did not ratify ILO (International Labour Organization) agreements on the abolition of forced labour in its colonies until I956, while Britain had already complied with international labour standards in 1930 and France in 1937.

The strategic choice of colonial governments was to raise monetary taxes in order to push the population into wage labour, as well as to promote wage labour to be able to raise taxes, as we will argue below. However, wherever cash tax payments and wage labour were not effective, forced labour practices were used as a complementary tool not only to save expenditure, but also to impose discipline.

A number of studies have recently reconstructed historical taxation in Africa from colonial budget accounts and aimed to explain regional differences in fiscal capacity. ${ }^{28}$ The present study adds the case of Mozambique to this literature, which has largely neglected Portuguese Africa. Like Feger and Asafu-Adjaye, and Mkandawire, we argue that colonial labour practices, categorized along the scheme suggested by Samir Amin, can explain differences in taxation. By contrast, we provide empirical evidence on taxation and labour practices on a yearly basis for a large part of the

25. Marlous van Waijenburg, "Financing the African Colonial State: The Revenue Imperative and Forced Labour", AEHN Working Paper 20 (2015). Unfortunately, consistent data on forced labour at a district level are not available for this exercise for Mozambique.

26. Zachary Kagan-Guthrie, "Repression and Migration: Forced Labour Exile of Mozambicans to São Tomé, I948-1955”, Journal of Southern African Studies, 37:3 (201 I), pp. 449-462.

27. Bridget O'Laughlin, "Proletarianisation, Agency and Changing Rural Livelihoods: Forced Labour and Resistance in Colonial Mozambique”, Journal of Southern African Studies, 28:3 (2002), pp. 5 I I -530 .

28. Frankema and Van Waijenburg, "Metropolitan Blueprints"; Jens Andersson, "Fiscal Capacity and State Formation in Francophone West Africa I 8 50-2010", AEHN Working Paper 22 (201 5); Thilo Albers and Marvin Suesse, "Colonial Fiscal Institutions in Africa: How They Persisted, When They Changed, and Why”, unpublished working paper (2015). 
colonial period. In a historical narrative, we also aim to unravel the connection between the two.

\section{HISTORICAL B A CK GROUND}

\section{From prazo feudalism to colonial concession companies and state administration}

In the explorations era (fifteenth century), a few trading posts and harbours were established by the Portuguese on the coast of Mozambique and along the Zambezi river. From the eighteenth to the nineteenth century the Zambezi region in the centre of Mozambique was dominated by prazo holders. Prazos were originally land tracts granted by the Portuguese Crown to Portuguese merchants. However, through intermarriage the prazo community became a mix of Portuguese and Africans. Prazo holders controlled large amounts of land, with the support of strong armies consisting of indigenous people. In the mid-nineteenth century, Portuguese activities in eastern Africa were focused mainly around these settlements along the banks of the Zambezi. ${ }^{29}$ A direct tax called mussoco was imposed on the indigenes by the prazos, which until the I 900 s was usually paid in kind. ${ }^{30}$ The economy was mainly based on agriculture, but prazo holders were also heavily involved in the slave trade. This region, at the centre of Mozambique, was characterized by a long tradition of trading coercive labour. Clandestine slave trading continued in Mozambique even after the I 842 Anglo-Portuguese agreement had attempted to prevent it. ${ }^{3 \mathrm{I}}$ Slave trading was one of the main factors causing depopulation and labour shortage in Mozambique during early colonization. Indigenous people often emigrated to avoid being recruited by force.

By the I 850 , local peasants from the south of the colony were moving to Natal in South Africa to work on plantations, while from the i 870 s onwards they started to migrate to the diamond mines in Kimberley and from I 886 to the gold mines in Transvaal. ${ }^{32}$ In contrast, in northern Mozambique Africans still had access to land and subsistence production as well as to markets. For centuries, the population of the north had conducted trade with Arabs, who established trading centres and sultanates on the

29. M.D.D. Newitt, "The Portuguese on the Zambezi: An Historical Interpretation of the Prazo System", Journal of African History, Iо:I (1969), pp. 67-85, 67.

30. Shubi L. Ishemo, "Forced Labour, Mussoco (Taxation), Famine and Migration in Lower Zambezia, Mozambique, I 870-1914", in Abeye Zegeye and Shubi Ishemo (eds), Forced Labour E Migration: Patterns of Movement within Africa (New York, 1989), pp. 109-158.

3I. M. Anne Pitcher, "Sowing the Seeds of Failure: Early Portuguese Cotton Cultivation in Angola and Mozambique, I820-1926", Journal of Southern African Studies, 17:I (1991), pp. $43-70,50$.

32. Ibid., p. 49 . 
coast of eastern Africa. This commerce and the ability of peasants to continue with their livelihood partially explain why from the I89os onwards concession companies had difficulties controlling northern Mozambique.

Under the international pressure of the Scramble for Africa in the I 880 s, Portugal had to secure and expand the "effective occupation" of its African territories. By the I 890 , five different cultural and political regions could be distinguished in Mozambique: a coastal zone under Portuguese control; a northern region of peasant agriculture, still under the influence of Islamic chiefs who performed long-distance trade; the central region of the Zambezi valley inhabited by prazos (albeit in decline); the African kingdom of Gaza and the Delagoa Bay (today Maputo Bay) in the south. ${ }^{33}$ After the defeat of the Gaza kingdom (I895) and the gradual integration of prazos into the colony, the political and cultural differences between these regions led to the formation of three zones (north, centre, and south) with distinct economic systems that persisted throughout the twentieth century. Each zone consisted of three districts that, in some cases, changed names over time. We harmonize the district names and boundaries according to the regional division of 1959 to 1973. The north comprises Niassa, Cabo Delgado, and Mozambique; the centre, Zambezia, Tete, and Manica e Sofala; and the south, Inhambane, Gaza, and Lourenço Marques (see Figure I).

In order to facilitate the establishment of its colonial rule, from the I 890 , Portugal delegated the administration of central (and part of northern) Mozambique to chartered companies, which were allowed to raise taxes, to exploit natural resources (land and minerals), and to have their own police force. This expenditure-saving practice was used by other colonial powers in Africa, such as in Belgian Congo and British Northern and Southern Rhodesia. However, the Belgian and the British colonial powers abolished the concessions of administrative authority in 1908 and 1924 , respectively. In Mozambique, three companies shared around fifty per cent of the whole colony's territory: the Niassa Company (I89I-I929) was active in the northern zone; the Mozambique Company (I89I-1942) and the Zambezia Company (I 892) operated in the central zone. The Zambezia Company was a leasing company (founded without a charter) and became the largest of the three. The concessions were considered ineffective in terms of capital accumulation and tax revenue and were not renewed by Salazar's "New State" regime that dominated Portuguese imperial politics from I 932 to $1974 \cdot{ }^{34}$

33. Malyn Newitt and Corrado Tornimbeni, "Transnational Networks and Internal Divisions in Central Mozambique”, Cabiers d'études africaines, I92 (2008), pp. 707-740, 710.

34. The Estado Novo was a corporatist and authoritarian regime, introduced by António de Oliveira Salazar in 1932 and followed by Caetano's governance from 1968 to 1974, when it was overthrown by the Carnation Revolution in Portugal. 


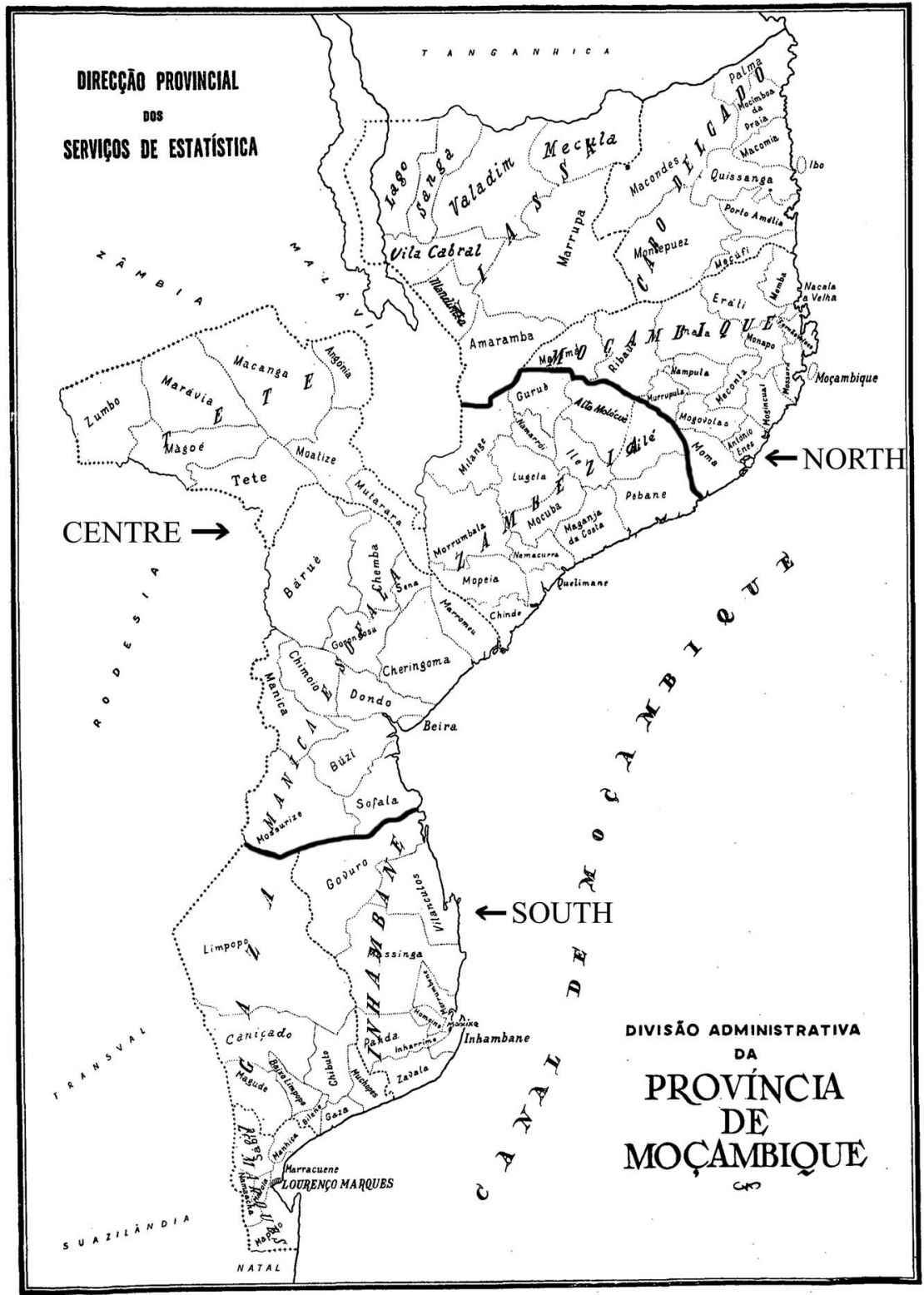

Figure I. Map of Mozambique showing districts.

Source: Repartição Central de Estatística Geral, Anuario Estatístico de Moçambique (1963). 
The role of concession companies in the economic integration of Mozambique has been vehemently debated, for instance by Neil-Tomlinson and Vail. ${ }^{35}$ The former praised the role of the Mozambique Company as central in the country's economic activity. He justified labour extraction and forced cash crop production on the basis of difficult climatic conditions and low population as well as in terms of an optimum ratio of investment to profit. ${ }^{36}$ In contrast, Vail criticized the role of the Mozambique Company and argued that it "failed to provide development and to stimulate a truly integrated local economy". ${ }^{37}$ In administrative terms, the division between colonial state and company rule was an impediment to the unification of the distinct zones of Mozambique. For instance, no efficient road connected the north to the south of the country until the I960s: "Road building remained the responsibility of the local authorities and no network was created to link different regions of the colony until the last decade of colonial rule". ${ }^{38}$

For decades Mozambique was characterized by a dual-racial system of local governance similar to those existing elsewhere in Africa: the indigenato. The indigenato code was formally adopted in 1928 and was in place until 1962. It was based on previous arrangements of citizenship and governance, and it subordinated Mozambican subjects to tribal chiefs and Portuguese citizens to colonial administrators. ${ }^{39}$ For the indigenes the indigenato meant that, first, they were forced to work (they had the "moral" obligation to do so) or alternatively produce agricultural surplus for the market; second, they had to pay taxes. If they could not fulfil their tax obligations, they could be recruited by colonial officials for forced labour. In that period local chiefs (regulos) and administrative assistants (cabos) were responsible for hut tax collection and forced labour recruitment ${ }^{4 \circ}$ and were paid by the colonial state through commissions. ${ }^{4 \mathrm{I}}$

Portuguese colonial officials justified the institutionalization of coercive labour in Mozambique on the basis of the following argument: African

35. Barry Neil-Tomlinson and Leroy Vail, "Discussion: The Mozambique Company", Journal of African History, i 8:2 (1977), pp. 283-286.

36. Ibid., pp. $283-285$.

37. Ibid., pp. $285-286$.

38. Newitt and Tornimbeni, "Transnational Networks", p. 71 2.

39. Mahmood Mamdani, Citizen and Subject: Contemporary Africa and the Legacy of Late Colonialism (Princeton, NJ, 1996).

40. In Angola, as elsewhere in Portuguese Africa, native chiefs were involved in the tax collection after the I9Ios. In the I920s, they were often punished if they did not cooperate with the Portuguese administration. Also, in several cases chiefs became agents of resistance. See Alexander Keese, "Taxation, Evasion, and Compulsory Measures in Angola”, in Philip J. Havik, Alexander Keese, and Maciel M. Santos, Administration and Taxation in Former Portuguese Africa, 1900-1945 (Newcastle upon Tyne, 2005), pp. 98-I37, I 20-I 22.

4I. Allen Isaacman and Barbara Isaacman, Mozambique: From Colonialism to Revolution, I900-1982 (Boulder, CO, I983), p. 29. 
industriousness had to be stimulated and development projects had to be promoted in order to raise the living standards of indigenous people. Forced labour came under the same regulation umbrella as wage labour. According to the Regulamento do Trabalho Indigena (I 899), those "who do not fulfil voluntarily the obligation to work [...] will be compelled by the authorities to do so". ${ }^{42}$ Under effective occupation the argument of labour shortage became more prevalent. Because of large migration streams to foreign countries throughout the colonial period, demand for labour from the side of both the private and the public sectors was always higher than the available supply. Since neither the colonial state of Mozambique nor the companies based there were able to compete with the wages offered in South Africa, Portuguese colonial rule established various forms of forced labour. In I926, it reintroduced forced labour (chibalo), based on the I 898 regulation, but enforced it much more systematically. The idea was to make the colonies the provider of raw materials and markets for the industry of Portugal.

In the late i950s, forced labour was banned and there was a general shift in the metropole towards more developmental policies. It was mainly the international pressure to abandon forced labour - also as a requirement to join international organizations - as well as the rise of anti-colonial sentiments in the metropole that led to this political tide. Starting in 1953, six-year development plans fostered investments of $\mathrm{I} 80$ million escudos in Mozambique, at first in infrastructure and communication and finally in agriculture, education, and health, however benefiting mainly the white population. ${ }^{43}$ But the outbreak of the African independence movements in the I960s made military investments a priority again.

\section{The way to gold: Institutionalizing migration labour in the south}

In the vein of Samir Amin, the south of Mozambique (Inhambane, Gaza, and Lourenço Marques districts) functioned as a labour reserve for the surrounding gold mines and European farms. Since the first discoveries of diamonds in Kimberley (South Africa) in I 867, and especially of gold in the Witwatersrand in 1886 , southern Mozambican migration to the mining centres had been crucial. The tradition of migration to South Africa has even earlier roots in the mid-nineteenth century, when sugar growers in Natal started to recruit labour in the Portuguese colony. Thus, migration from the south of Mozambique was clearly an early colonial phenomenon

42. Cited in James Duffy, Portuguese Africa (Cambridge, MA, 1959), pp. I55-1 56.

43. Jeanne Penvenne, "Settling against the Tide: The Layered Contradictions of TwentiethCentury Portuguese Settlement in Mozambique", in Caroline Elkins and Susan Pedersen (eds), Settler Colonialism in the Twentieth Century: Projects, Practices, Legacies (New York, 2005), pp. 79-94, 84 . 


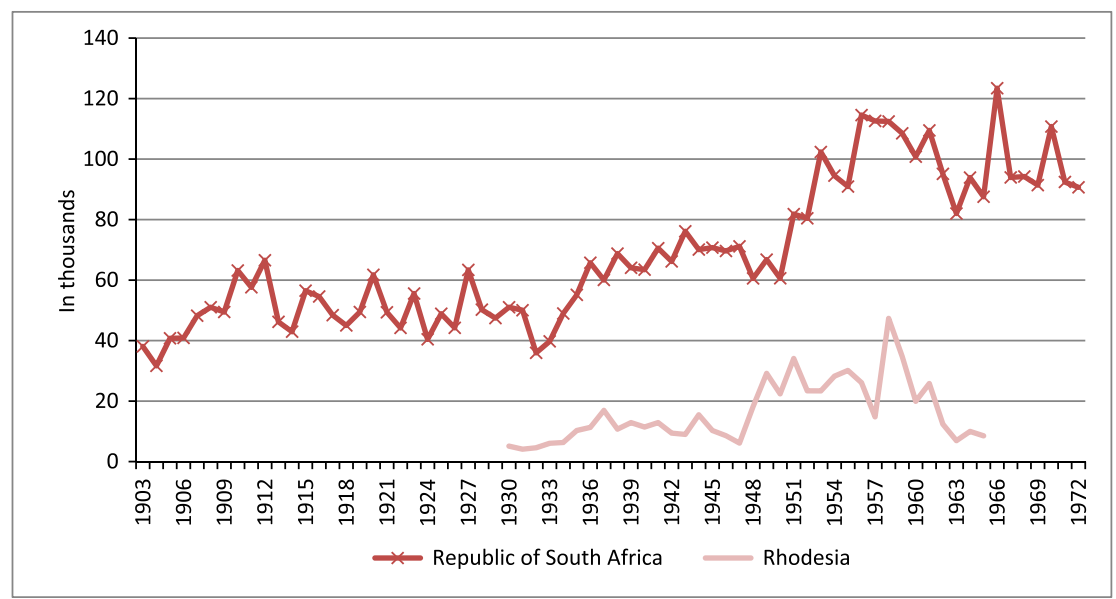

Figure 2. Total number of migrants from Mozambique to the mines of South Africa and to Rhodesia per year.

Sources: I900s-1920s: "Direcção dos Serviços dos Negócios Indígenas", Movimento da emigração, vol. I Cx 48, in Arquivo Histórico de Moçambique; I930s-I970s: Repartição Central de Estatística Geral, Anuários Estatísticos.

that the Portuguese colonial authorities used to make profit and foster fiscal capacity.

As Figure 2 shows, until 1930 on average 50,000 people per annum temporarily migrated from Mozambique (principally from the southern part) to the mines of Transvaal until 1930, and the numbers doubled until the late I960s. Migration diminished in the I970s when the Frelimo movement closed several recruitment centres operated by the Witwatersrand Native Labour Association (WNLA), and it remained low until 1984 . The recorded numbers include both legal and illegal migration; the colonial office also kept records of "clandestine migration" (or nonrecruited migrants), which usually accounted for around thirty per cent of the total. Until the mid-I970s, Mozambique provided the largest share of workers to the mines of South Africa. ${ }^{44}$ Migration to Southern Rhodesia, also recorded in the statistical yearbooks and portrayed in Figure 2,

44. Ruth First, Moira Forjaz, and Alpheus Manghezi, O mineiro moçambicano. Um estudo sobre a exportação de mão de obra de Inhambane (Maputo, 1998), p. 204. In 1904, Mozambican workers as a proportion of the total number of miners in South Africa was sixty-six per cent and in I 920 it was fifty-six per cent. In 1936, it decreased to twenty-eight per cent but, in 1956, it rose again to fifty-five per cent. Finally, by 1970, it had dropped to twenty-eight per cent owing to the increasing influence of the Frelimo independence movement, which criticized the huge migration streams from Mozambique and especially the surplus extraction on the part of the apartheid regime in South Africa. 
was mainly transitory migration to South Africa. Since the border between Mozambique and South Africa was under tight control, clandestine migrants used a route that went through Southern Rhodesia. However, several Mozambicans also engaged in farm labour there, usually to save money to continue their route to South Africa, where wages were higher. ${ }^{45}$

Historians have argued that the large-scale exploitation of gold reserves in South Africa would never have been profitable without the mobilization of large numbers of unskilled and low-paid indigenous labourers from throughout southern Africa. ${ }^{46}$ But it was not only the mining companies and the state of South Africa (increasingly interventionist and cooperating with the private sector) that profited from migration labour; the providing states too secured large revenues from the migration flows to the mines. In more recent times, in the I990s, almost a third of Mozambique's GDP derived from migrant miners' wages. ${ }^{47}$ In the early colonial period, mining labourers belonged to the few who earned money in cash, and could therefore contribute to the fiscal revenue of the colonial state by paying direct taxes. Although rural households also profited from the remittances sent by the migrants, the high emigration streams certainly affected the rural areas of the southern districts of Mozambique, which were periodically deprived of the presence of able-bodied young men to help with the harvest.$^{48}$ For instance, in Inhambane in the 1940s between twenty-six and thirty-one per cent of the male active population was away at any time of the year. ${ }^{49}$ A further negative consequence of migration may have been that it promoted forced labour practices in the southern part of Mozambique. Allina refers to forced labour as one of the economic and political consequences of labour shortage, created by labour migrating from Mozambique to South Africa and Rhodesia: "intense economic competition in southern Africa led Portugal to rely on forced labour to develop and protect her claims to her colonies". 50

45. David Johnson, "Clandestine Migration in South Central Africa”, Collected Seminar Papers Institute of Commonwealth Studies, 40 (1990), pp. I-I I.

46. Charles H. Feinstein, An Economic History of South Africa: Conquest, Discrimination and Development (Cambridge, 2005). In 1912, the Chamber of Mines granted the monopoly of recruiting to two organizations, allowing uniform recruiting policies and the control of wage levels: the Native Recruiting Corporation (NRC), which operated in South Africa, and the WNLA, operating elsewhere. Moreover, the recruitment system that was put in place allowed labour to be mobilized from ever more distant and poorer regions, where people would still work for the prevailing low wages.

47. Jonathan Crush, Alan Jeeves, and David Yudelman, South Africa's Labor Empire: History of Black Migrancy to the Gold Mines (Oxford, 199I), p. 2.

48. Jelle van den Berg, "A Peasant Form of Production: Wage-Dependent Agriculture in Southern Mozambique", Canadian Journal of African Studies, 2 1:3 (1987), pp. 375-389.

49. Malyn D. Newitt, $A$ History of Mozambique (London, I995), p. 501.

5o. Eric Allina, “'Fallacious Mirrors': Colonial Anxiety and Images of African Labor in Mozambique, ca. 1929", History in Africa, 24 (1997), pp. 9-52, I 2. Penvenne, on the other hand, 
The Portuguese colonial government soon realized that it had to take control of the migration streams in order to profit from them through taxation and other fees. It signed a long series of inter-state contracts with South Africa that strictly regulated the "export" of labour, starting in I $897 .{ }^{\text {I }}$ On both sides of the border, control posts were set up to keep track of the migrant movements. In order to have better control of migration streams, a curatorship was established in Johannesburg, which could also legalize the situation of Mozambican clandestine migrants by issuing passports, so that mining companies could engage them.

In the Portuguese Labour Agreement with Transvaal of I90I, the Modus Vivendi, and essentially all subsequent agreements, the period of service of workers in the mines was set to twelve months and could be extended by a further six months. ${ }^{52}$ When the contract ended, the workers had to be sent back to Mozambique in order to spend their earnings at home. These agreements also granted monopolistic permission to recruit labour in Mozambique to the WNLA until i965; later, three other recruitment organizations gained permission. Both governments set the salaries for the migrant workers. These were relatively low, due to the monopoly of labour recruitment granted to the WNLA by the Chamber of Mines of Transvaal and by the government of Mozambique.

Other terms of the agreement included the prohibition on recruiting above $22^{\circ}$ latitude (just below the frontier of the territory of the Mozambique Company) - except for a short time between 1908 and I9I $3 .{ }^{53}$ Thus, the WNLA recruited only in the three southern districts: Inhambane, Gaza, and Lourenço Marques. This limitation was imposed by Mozambique to address the complaints of companies and settlers

considers forced labour practices in Mozambique as a cause of increasing migration and labour scarcity at a national level, since many indigenous people migrated legally or illegally to neighbouring countries in order to avoid the risk of being sentenced to forced labour in Mozambique. She presents shibalo (forced labour in southern Mozambique) as a push factor for both internal and external migration. First, it forced peasants out of their home region to work on plantations and in public works. Second, it diminished free wage labour opportunities and wages within Mozambique and encouraged external migration. See Jeanne Penvenne, African Workers and Colonial Racism: Mozambican Strategies and Struggles in Lourenço Marques, I877-1962 (Portsmouth, NH, 1995). Indeed, forced labour can be perceived either as a push factor for migration, from the perspective of indigenous people, or as the consequence of labour shortage caused by migration, from the perspective of colonial rule. In any case, it was a significant link in the "chain" of taxation-labour-monetization, especially in the northern and central zones of Mozambique, as we explain in the following subsections.

5. First et al., $O$ mineiro moçambicano, pp. I 8-19.

52. Alan H. Jeeves, Migrant Labour in South Africa's Mining Economy: The Struggle for the Gold Mines' Labour Supply, I890-1920 (Montreal, I985), p. 217.

53. First et al., $O$ mineiro moçambicano, p. 2 I. 


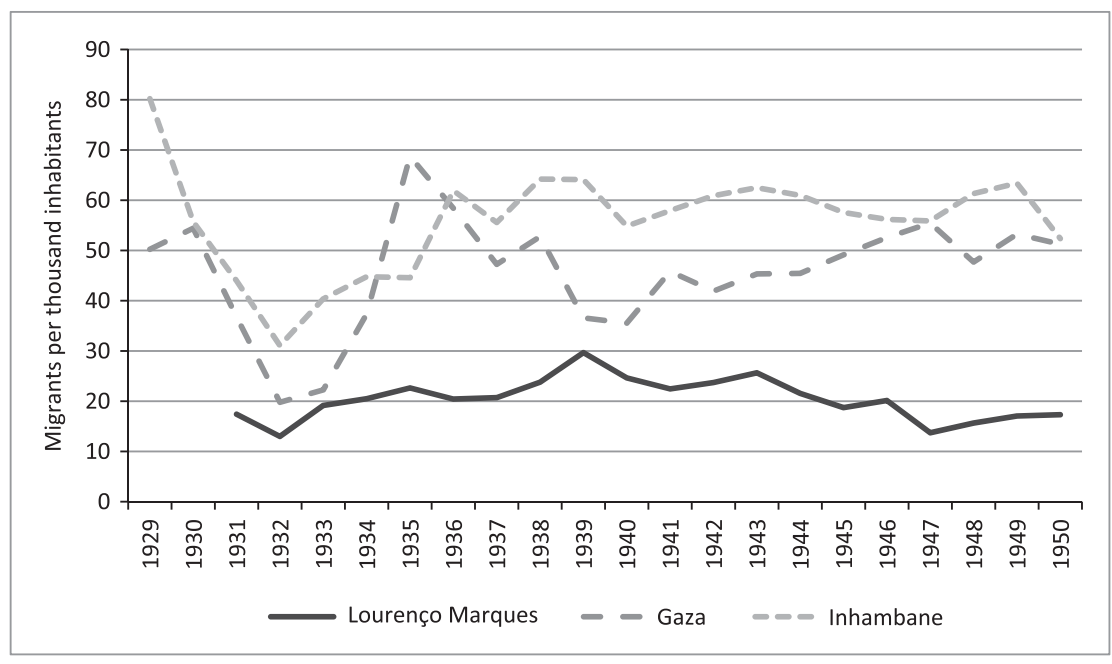

Figure 3. Migrants from southern districts to Transvaal, South Africa. Source: Repartição Central de Estatística Geral, Anuários Estatísticos.

about scarcity of labour and the inability to compete with wages paid in South Africa. It did not prevent residents of the northern districts from travelling to the recruitment stations, but actually most migrants originated from the three southern districts. In the statistical yearbooks, between only ten and thirty per cent of those emigrating between I 929 and I950 are listed not as leaving one of the three southern districts, but as originating from an "unknown district" (see Appendix A). Figure 3 displays the proportion of migrants per I,, 00 inhabitants from each of the three southern districts. Inhambane is almost consistently the district that sent most migrants to Transvaal relative to its population (between thirty and eighty per thousand inhabitants), followed by Gaza (with around twenty to fifty per thousand inhabitants), and Lourenço Marques (around eleven to thirty migrants per thousand inhabitants).

The Lusitanian colonial government charged recruitment licences as well as passport issuing fees to the recruiting organizations for each Mozambican employee. Furthermore, a migration tax was collected at the border with South Africa. Portuguese success in profiting from migration streams to South Africa, Southern Rhodesia, and São Tomé is reflected in the amount of revenue raised from migration, listed as such in the statistical yearbooks (this excludes indigenous taxes). The sources of revenue include licences for recruiting personnel; migration, passport, and registration taxes; re-engagement fees; and other payments, which were largely raised in the curatorship of Transvaal; smaller amounts were collected in Southern Rhodesia and at the Ressano 
Table I. Total revenue raised from migration, also as a share of total direct tax revenue.

\begin{tabular}{lccc}
\hline & $\begin{array}{c}\text { Total revenue raised from migration } \\
\text { (to Transval, Rhodesia, São Tomé) }\end{array}$ & $\begin{array}{c}\text { Average total } \\
\text { direct tax }\end{array}$ & $\begin{array}{c}\text { Migrant tax/ } \\
\text { toral direct tax } \\
\%\end{array}$ \\
\cline { 2 - 4 } for years & in constant 1954 escudos & & 25 \\
$1941-1945$ & $62,505,585$ & $245,590,527$ & 19 \\
$1946-1950$ & $47,958,187$ & $258,505,152$ & 19 \\
$1951-1955$ & $52,357,034$ & $273,647,258$ & 19 \\
$1956-1957$ & $55,655,917$ & $294,507,807$ & 19 \\
\hline
\end{tabular}

Source: Repartição Central de Estatística Geral, Anuários Estatísticos; price deflator: Nuno Valério, Estatísticas históricas portuguesas (Lisbon, 200I).

Garcia border post. ${ }^{54}$ To put it into perspective, in the I 940 and I950s total revenue raised from migration represented around twenty per cent of total direct tax revenue (see Table I).

To collect indigenous taxes from migrants working in the mines of Transvaal effectively, direct taxes were also paid at the Portuguese curatorship in Johannesburg and in Southern Rhodesia. The direct tax revenue collected outside Mozambique accounted for five to ten per cent of total direct tax revenue throughout most of the time under study. ${ }^{55}$ Another important advantage for the Portuguese government derived from the stipulation that a large share of the migrant workers' salary be deferred to the completion of their terms in the mines and paid directly after their return to their home country. ${ }^{56}$ It ensured that the workers returned to Mozambique and spent their earned cash at home, thereby contributing to the monetization of the economy. Given that the districts that sent migrants to South Africa became the most monetized areas, the largest share of the direct tax revenue of Mozambique could be paid by the population of this southern region.

As for the living conditions of migrant labourers in the mines and compounds, much has been written in a seminal work by Patrick Harries, ${ }^{57}$ so these will not be discussed extensively here. Both during the transportation of migrant labourers from far-away regions to Transvaal and in the mines and compounds, mortality and morbidity were considerable. A racial

54. Repartição Central de Estatística Geral, Anuário Estatístico (Lourenço Marques, 194I), p. I 20.

55. Repartição Central de Estatística Geral, Anuário Estatístico (Lourenço Marques, I926-1973). 56. In 1928, a new agreement was ratified by the Union of South Africa and Portugal: South Africa gained greater control over the Transvaal / Lourenço Marques railway line as well as over the port of Lourenço Marques, and the colonial state of Mozambique ensured that the system of deferred pay was made compulsory.

57. Patrick Harries, Work, Culture, and Identity: Migrant Laborers in Mozambique and South Africa, c. I860-1910 (Portsmouth, 1994). 
labour regime that prevented indigenous people from entering skilled and semi-skilled jobs emerged for the first time in the mines (both Kimberley and Transvaal) and marked the beginning of the apartheid labour policies later applied to all industries in South Africa. As Appendix B shows for 1930 to 1950, average indigenous migrant miners' wages decreased significantly in real terms throughout this time, as they did for the remainder of the twentieth century. ${ }^{58}$ However, wages were higher in the Rand gold mines compared with those paid for unskilled (and mostly forced) wage labour by the state and the private sector in Mozambique. Thus, migrating to the mines was probably the most appealing alternative for men living in rural areas, given the obligation to work and the pressure to earn cash wages imposed on the indigenous population through colonial taxation.

We can conclude that colonial rule in Mozambique invested in controlling and promoting a pre-existent migratory phenomenon, which represented a rich source of revenue, especially in the form of direct taxes. Furthermore, we can assume that the fact that the capital city was located in the south and that there was probably a larger concentration of colonial officials there facilitated control and tax collection in this area, compared with more remote areas with less official European presence.

Apart from functioning as a migrant labour pool, this zone experienced a boom in settler migration from Portugal in the I940s, due to the attempt of the colonial government to attract white population, ${ }^{59}$ which made the development of a European farm economy possible. As a result of successful state assistance to Portuguese settlers, ${ }^{60}$ the south became more competitive in terms of agricultural production and trade. Consequently, European farms became an additional source of employment for indigenous people wanting to gain cash wages.

\section{Centre: The land of concessions and forced labour}

The centre (Zambezia, Manica e Sofala, and Tete districts) fits the category of the "Africa of concessions". Traditionally, the prazo holders dominated part of this region and this institution was not completely abolished after the "effective occupation" (I 890 ) by Portugal, but most of the land was

58. Our calculation of wages is based on the total amount that migrant labourers received in wages divided by the number of migrants, adjusted by the Consumer Price Index. Wages rose considerably again in the I970s due to the need to attract unskilled labour because the migrant labour regime collapsed. See Francis Wilson, "International Migration in Southern Africa", The International Migration Review, I0:4 (1976), pp. 45 I-488.

59. Cláudia Castelo, Passagens para África. O povoamento de Angola e Moçambique con naturais da metrópole (1920-1974) (Porto, 2007).

60. Bridget O'Laughlin, "Class and the Customary: The Ambiguous Legacy of the Indigenato in Mozambique”, African Affairs, 99:394 (2000), pp. 5-42, I0. 
leased to commercial companies. Thus, in the first few decades of colonial rule (up to 1942) the central districts were controlled by the (mostly foreign-owned) ${ }^{61}$ "Mozambique Company" (south of the Zambezi, district of Manica e Sofala) and the "Zambezia Company" (north of the Zambezi, districts of Zambezia and Tete).

The centre was governed in the interests of the concession companies. It was important for colonial rule to attract capital for plantations and foster "development", and therefore the administration provided cheap labour for these plantations. This was achieved by introducing the indigenous hut/poll tax, by forbidding payment in kind, and by introducing legislation forcing the population to work. The so-called indigenato institution forced the indigenous population to work almost throughout the colonial period. ${ }^{62}$ Coercive labour either in public works or on plantations was remunerated, reaching minimum wage levels in the late colonial period. ${ }^{63}$ Cases of abuse, illegal extension of contracts, underpaid or withheld wages, and unjust treatment by local officials were not uncommon. ${ }^{64}$

The contract of the Mozambique Company with the Portuguese Crown in Manica e Sofala was prolonged until 1942 by the Republicans, ${ }^{65}$ but it was not then renewed by Salazar's regime, which aimed for budget balance and centralization. ${ }^{66}$ As the Governor of Manica e Sofala stated, the companies "did nothing to develop the potential wealth of this entire region, preferring to plunder it and alienate the natives". ${ }^{67}$ Also, the

6r. For example, the Mozambique Company was established with a capital stock of about five million dollars obtained from financiers from Germany, the United Kingdom, and South Africa. Isaacman and Isaacman, Mozambique: From Colonialism to Revolution, reports that the firm was capitalized at 40,000 pounds, and that British and French capital quickly predominated.

62. O’Laughlin, "Proletarianisation".

63. Penvenne stresses that the annual income of forced labourers would be equivalent to less than half of the annual income of free native labourers: "Ordinary municipal 'native' laborers earned 5,260\$00 a year, and municipal shibalo labor earned less than half that amount, 2,160\$00"; Penvenne, African Workers and Colonial Racism, p. 5. In the southern province of Sul do Save workers in agricultural enterprises and in the railway and street construction sectors received I 50 escudos per month and in the industrial sector they received I 80 escudos. In the province of Manica e Sofala the workers' monthly wage ranged from sixty to r 30 escudos, while in central Zambezia it ranged from sixty to ninety escudos. Finally, in the poorest northern province of Niassa workers received fifty to ninety escudos for their services. See "Inspecção superior dos negocios indígenas", Lourenço Marques, I95I, in Arquivo Histórico de Moçambique.

64. E.A. Ross, Report on Employment of Native Labor in Portuguese Africa (New York, 1925). 65. The First Portuguese Republic lasted sixteen years, from the fall of the constitutional monarchy in I9I I to the coup d'état of I 926 that led to the Estado Novo regime of Salazar.

66. The contract stipulated that only 7.5 per cent of the profit had to be granted to the colonial state. See Eric Allina, Slavery by Any Other Name: African Life Under Company Rule in Colonial Mozambique (Charlottesville, VA, 20I2).

67. Isaacman and Isaacman, Mozambique: From Colonialism to Revolution, p. 37. 
Zambezia Company did little more than sublease its land to the initial occupiers and rulers of the land, thus the prazo holders managed to survive and keep their lands. ${ }^{68}$

In the last few years of the concession companies, the metropole allowed smaller private companies to operate in the region and produce cash crops (sugar, tea, and cotton). Sena Sugar Estates Limited became the colony's largest producer and exporter. However, due to the rising demand for cotton from the metropolitan textile industry, Portugal introduced forced cotton cropping in certain zones of Mozambique in 1926, the same year as the military coup that overthrew the Republican government. ${ }^{69}$ In Zambezia, this was done by means of concessions to small private companies. In I938, the Cotton Export Board was established to supervise the cotton industry in the colony. According to Vail and White, ${ }^{70}$ the production and export of cotton in sufficient quantities succeeded in Zambezia thanks to the ruthless imposition of forced labour regulation from the I940s. After insistent lobbying by the companies, the colonial authorities chose not to offer the carrot of paying higher prices to producers; instead they used the stick of coercion. ${ }^{7 \mathrm{I}}$

High labour scarcity, due to labour migration and rising competition between the companies in the region, led to repressive labour laws and extended use of coercive labour. ${ }^{72}$ As mentioned earlier, all adult males were obliged to work. If they cultivated the land, but did not sell their produce to the market and were not elsewhere employed on private plantations or infrastructure projects, they could be apprehended by the local authorities and used as forced labour. In early legislation (I909 and I9I 2), the contract period for forced labour could not exceed two years. ${ }^{73}$ Eventually, labourers had to offer their services for a period of three to six months each time, and received their full pay only at the end of the contract. In 1942, this system "was formally re-introduced in Mozambique by Circular 818/D-7", issued by the general governor of the colony, stating that vadios (vagrants) could expect to be arrested by the administrators and forced to work for a colonial enterprise. ${ }^{74}$

68. Newitt, A History of Mozambique, p. 678.

69. Allen Isaacman, "Coercion, Paternalism and the Labour Process: The Mozambican Cotton Regime 1938-1961", Journal of Southern African Studies, I8:3 (1992), pp. 487-526.

70. Leroy Vail and Landeg White, “'Tawani, Machambero!': Forced Cotton and Rice Growing on the Zambezi”, Journal of African History, I9:2 (1978), pp. 239-263, 249.

7I. Ibid., p. 25 I.

72. Judith Head, "Sena Sugar Estates and Migrant Labour", Mozambican Studies: Journal of Social Science, I (1980), pp. 53-7I.

73. Allina, "Fallacious Mirrors", p. I4.

74. Newitt and Tornimbeni, “Transnational Networks", p. 7 17. 


\section{"Mother of poverty": 75 Peasantry and cotton in the north}

The north (Cabo Delgado, Niassa, and Moçambique districts) was traditionally a peasant-based economy organized mainly by indigenous people, with trade bonds with British Nyasaland and German Tanganyika (today Malawi and Tanzania). Between i89i and I929, the northern region was not fully controlled by the colonial state. Most inhabitants were engaged in subsistence agriculture. In parallel, the British-owned Niassa Company was active in part of the territory and was allowed to force the indigenes to work on plantations and on infrastructure projects, as well as to pay the hut taxes that kept them indebted. This system enabled the Niassa Company to prevent the peasants from growing their own crops for sale and thus compete with the company's own production. However, the results in terms of production surplus and employment proved to be poor in this area, which is why the concession of the Niassa Company was not renewed by Portugal in 1929 .

The north was densely populated compared with the centre and the south, but this potential tax source remained untapped throughout the colonial period. The hut tax rate in the north was half of the rate paid in the south, but even so peasants could not afford it. In the I920s, tax revenue collection progressed, but it soon stagnated again, mainly due to the world economic crisis (1929-193I). During the depression, fiscal tension rose tremendously: the number of hut tax debtors increased fivefold. However, the "problem of Niassa" predated the crisis. The tax burden in the northern districts was high for the indigenous peasants, since they did not produce sufficient surplus to sell to the market and thus generate income in cash. The difficulty was greatest in the district of Moçambique, where the indigenous tax was raised "per capita", unlike the "hut" tax. ${ }^{76}$

Insufficient food production due to unsuitable soils, lack of infrastructure (access to markets), and delayed payment of low wages by the Niassa Company were impediments that led to low monetization and tax revenue. In the I930s, the local colonial administration responded in two ways: first, the circunscrição officials ${ }^{77}$ in Niassa started to under-register taxpayers to hide the poor performance in raising taxes; second, the law allowed fiscal debts to be paid in kind or in labour. ${ }^{78}$

75. The phrase "cotton is the mother of poverty" was introduced by Allen Isaacman et al., "'Cotton is the Mother of Poverty': Peasant Resistance to Forced Cotton Production in Mozambique, 1938-196I”, The International Journal of African Historical Studies, I 3:4 (1980), pp. $58 \mathrm{I}-6 \mathrm{I} 5$.

76. Maciel M. Santos, “An 'Obsessive Idea': Native Taxation in Northern Mozambique (1926-1945)”, WP/CEAUP (2007), p. 5.

77. Circunscrição is an administrative unit smaller than the distrito and bigger than the posto.

78. Santos, “An 'Obsessive Idea'”, p. 7. 


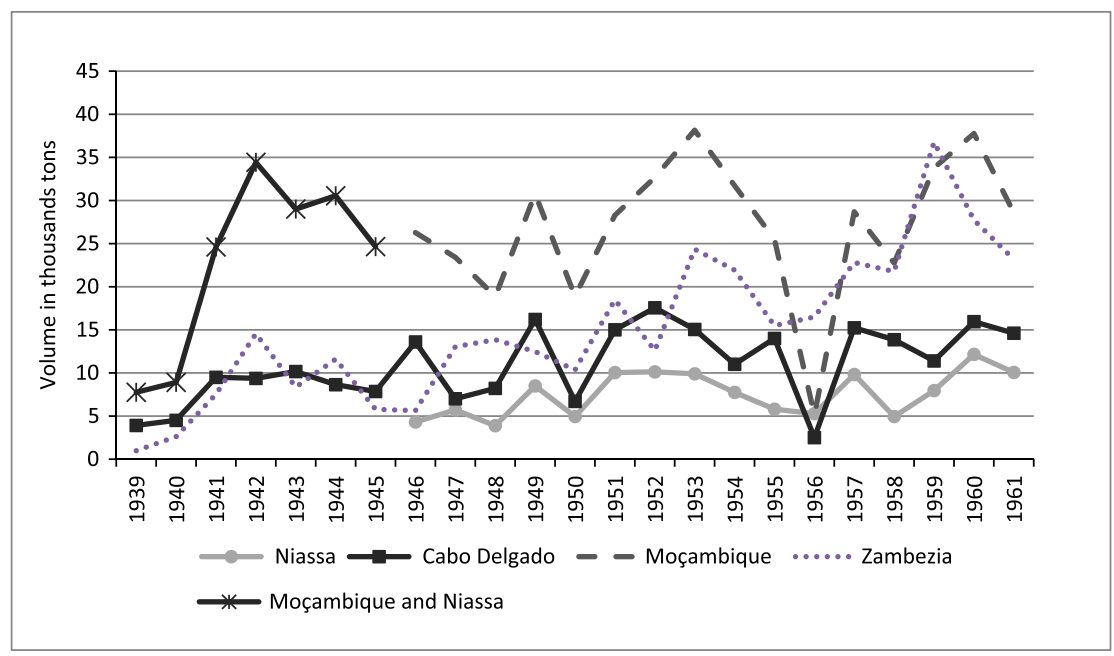

Figure 4. Production of raw cotton (volume in tons) by indigenes per district.

Source: Bravo, "A cultura algodoeira", pp. I36-I39. (Until I945 the district of Moçambique was part of a broader administrative unit, including the district of Niassa. From 1945 onwards Moçambique was a separate unit.)

In the period 1938-196I (under the metropolitan governance of Salazar), colonial policy severely reduced the autonomy of rural producers. In the late I930s, the Colonial Cotton Board defined cotton zones whose inhabitants were forced to cultivate the crop, diverting labour from food cultivation. It signed agreements with twelve firms that gained power over half the colony (three districts of the north, plus Zambezia in the centre). ${ }^{79}$ The population of the cotton zones was obliged to sell their produce to the cotton companies at below-market prices; the companies in turn processed the raw cotton in their ginneries and exported the cheap produce to Portugal. Since Portuguese presence was limited in these areas, the assistance of local chiefs was necessary to effectively implement the cotton regime. $^{80}$

Figure 4 shows the production of raw cotton per district. Production took off in 1940 after the introduction of forced cropping and it remained stable until 1961 (except for a severe drop in 1956 due to an extreme

79. Isaacman, "Coercion, Paternalism and the Labour Process", p. 493.

80. Ibid., p. 495. The Cotton Board defined zones where peasants could be forced to cultivate cotton; determined who was obliged to participate; fixed mandatory dates and times when rural communities had to plant, seed, and harvest their cotton crop; defined the various qualities of cotton; and finally, it helped to set the price paid to the peasants by the concessionary company. 
weather shock). ${ }^{8 \mathrm{I}}$ The district of Moçambique was the largest producer of cotton, followed by Zambezia.

This system resulted in growing hostility on the part of peasants towards the colonial state. According to Isaacman, the low output and "the artificially depressed prices set by the state left many rural households impoverished". ${ }^{82}$ The average income of the cotton producers (one dollar for a whole crop) did not suffice even to allow them to pay their taxes. Since yields and prices were low, several peasants withdrew from cotton cultivation to focus on food production. However, in the early I940s, officials further reduced the autonomy of peasants and imposed an extremely tough and controlling system of work obligations, without substantially raising prices. In short, the colonial cotton regime intensified the dynamics of impoverishment that were already present in this region.

\section{PERSISTENCE IN TAX INEQUALITY: EMPIRICAL RESULTS}

\section{Taxation in the three zones}

This section presents an empirical assessment of the differences in taxation between the three regions of Mozambique. We collected data on public revenue on an annual basis from 1930 until the end of the colonial period in I 973 from the "public administration" section of the statistical yearbooks and national accounts of the colony of Mozambique, found at the Instituto Nacional de Estatística in Lisbon. For the analysis, we chose to focus on direct taxes, because these are more difficult for the state to collect, and are therefore generally associated with greater state capacity, whereas indirect taxes, mainly derived from trade, are an easier source of extraction. ${ }^{83}$ Furthermore, direct taxation is more closely linked to indigenous labour policies and practices (as explained above) than taxing imports and exports. As mentioned earlier, hut and poll taxes constituted a relatively high share of total state revenue during colonial times in Mozambique, given that trade was relatively unimportant. Figure 5 shows that direct taxation contributed around fifty per cent of the value of total state revenue in the period under study (the corresponding figure in the I940s was around sixty per cent, falling to around forty per cent in the I950s, before rising again to fifty per cent and then sixty per cent again in the I960s and I970s, respectively). ${ }^{84}$

81. Nelson Saraiva Bravo, "A cultura algodoeira na economia do norte de Moçambique", Junta de Investigações do Ultramar, Centro de Estudos Políticos e Sociais, 66 (1963), p. I8 I.

82. Isaacman, "Coercion, Paternalism and the Labour Process", p. 498.

83. Herbst, States and Power in Africa.

84. As Figure 5 shows, the total tax revenue increased fivefold between I94I and I973, and the sharpest rise occurred in the last thirteen years, from one billion to almost r. 8 billion escudos. The reasons could be various, including the larger military expenses during the independence war (1964 to 1974). 


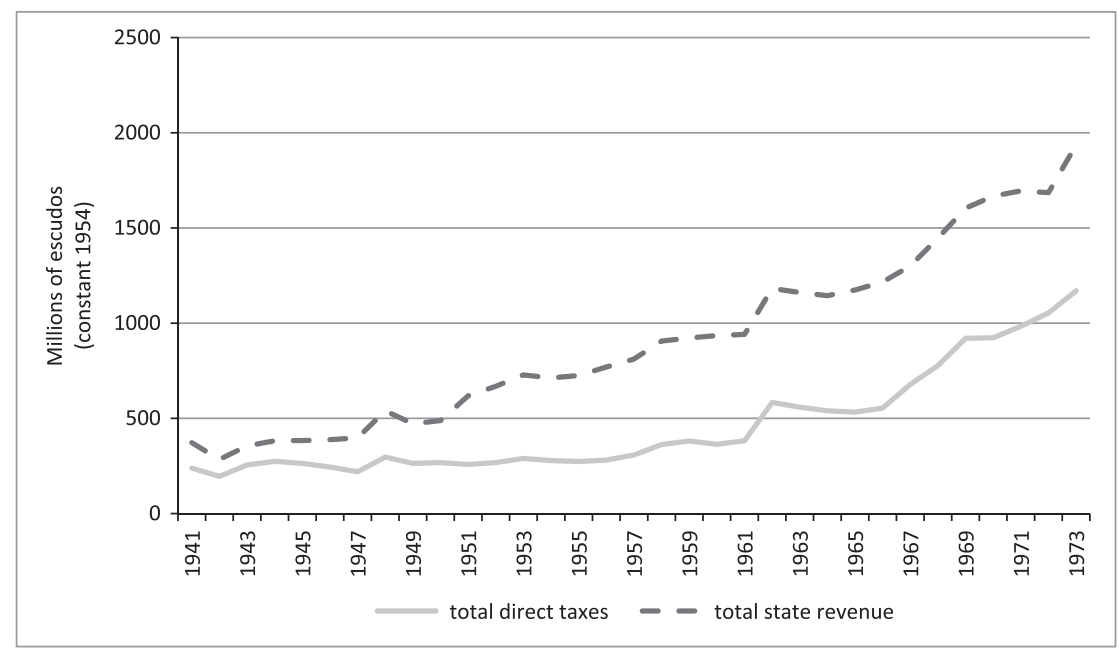

Figure 5. Total state revenue and revenue from direct taxation.

Sources: Repartição Central de Estatística Geral, Anuários Estatísticos; price deflator: Valério, Estatísticas históricas portuguesas.

We reconstruct real direct taxes per capita for the nine districts of Mozambique by dividing total direct tax revenue (eighty per cent of which was accounted for by indigenous taxes until $196 \mathrm{I})^{85}$ by the total population $^{86}$ of the corresponding district, and deflating the value by the consumer price index in Portuguese escudos, the currency in which the tax revenues are recorded. ${ }^{87}$ For one of the nine districts, Manica e Sofala, information appears in the statistical yearbooks only from 1943 onwards (until then this district was under the rule of the Mozambique Company, which enjoyed a high degree of autonomy and kept separate records). Figure 6 displays total real direct tax revenue per capita in the three zones between 1930 and 1973. It shows that tax revenue per capita differed strongly between the north, the centre, and the south, and the order was highly persistent over time.

In the I930s, average taxes in the south were three times the amount levied in the northern or central areas (excluding the district of Manica e Sofala, which was under concession company control until 1942). In this

85. European settlers paid direct taxes on their activities and assets (professional or property taxes) but did not pay personal income tax. However, after I96 I the indigenato system (informal colour bar) was ended and the indigenous tax was transformed into personal income tax, which also applied to the white population. This is probably why we see a sudden rise in total direct tax revenue in the I960s.

86. Population data are interpolated between censuses since censuses were carried out only every five or ten years.

87. Nuno Valério, Estatísticas históricas portuguesas (Lisbon, 2001), pp. 661-662. 


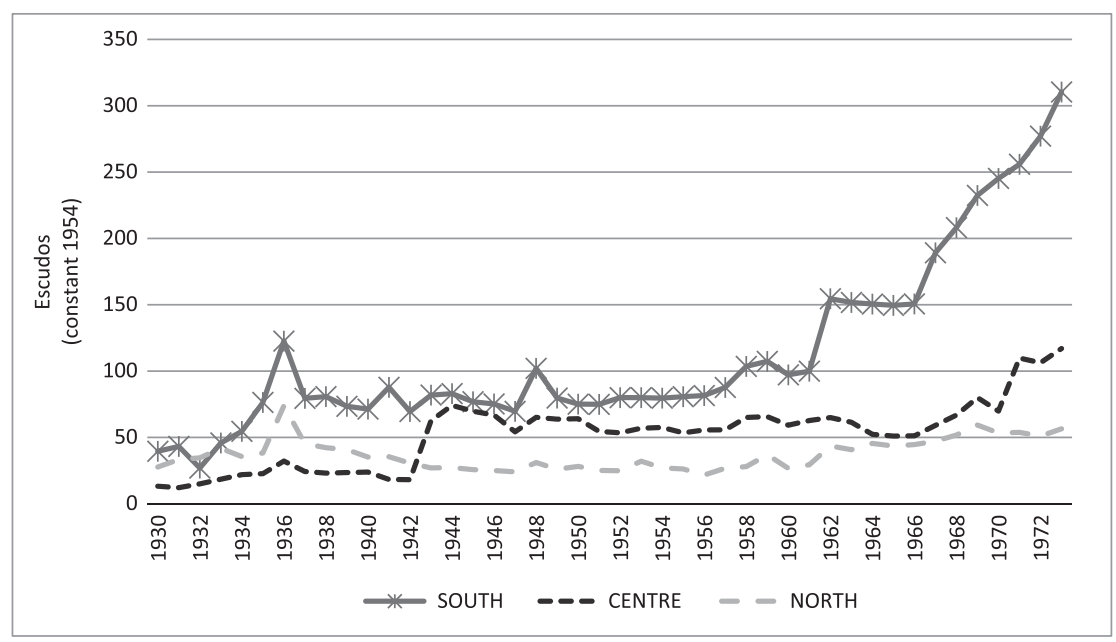

Figure 6. Real direct tax revenue per capita by zone.

Sources: Direct tax revenue and population: Repartição Central de Estatística Geral, Anuários Estatísticos; price deflator: Valério, Estatísticas históricas portuguesas.

decade, the per capita tax revenue in the north was slightly higher than in the centre, whereas between the I940s and I970s this trend was reversed and per capita tax revenue in the centre (including Manica e Sofala) was on average double that in the northern area ${ }^{88}$ In the last period, I970 to I973, in the south direct tax revenue per capita was around six times that of the north.

Thus, the three regions not only contributed disproportionately to total direct tax revenue, per capita direct tax revenue was also much higher in the south throughout colonial times until independence, an indication that tax capacity was strongest in the south and weakest in the north. The differences in tax revenue shown in Figure 6 might derive from two things (or both at the same time): differences in the number of people whom colonial officials could

88. Santos argued that in the I9I os the administrative districts of the south provided - in total, not divided by population - ninety per cent of the hut tax revenue, collected directly by the government, while the centre and the north together did not exceed ten per cent of the total. See Maciel Santos, "O imposto camponês no Norte de Moçambique (I929-I939). Um cultivo forçado, factor de crescimento?", Atas do Congresso Internacional "Saber Tropical em Moçambique. História, Memória e Ciência”, IICT - JBT/Jardim Botânico Tropical, Lisbon, 24-26 (October 20I 2), p. 2. The contribution of the northern and the central zones to total hut tax revenues in Mozambique gradually increased, and by the I940s the shares of the three zones to indigenous tax revenue became almost equal. See M.M. Santos, "Imposto e algodão. O caso de Moçambique (I9261945)", in Centro de Estudos Africanos da Universidade do Porto (ed.), Trabalho Forçado Africano. Articulações com o poder político (Porto, 2007), p. 20I. However, these findings do not take account of the size of the population in each zone. 
tax, and variation in the tax rates levied per person. The first mainly has to do with demographic and geographic factors, the second with economic and commercial features. We have scattered evidence on native tax rates in the different zones derived from official correspondence. In 1948, the indigenous tax rate in the southern zone (in the districts of Inhambane, Gaza, and Lourenço Marques) was 250 escudos on an annual basis, while in the central district of Manica e Sofala the rate ranged between one hundred and 2 ro escudos, depending on the circunscrição, and in the northern district of Niassa the rate ranged between eighty and 130 escudos. ${ }^{89}$

\section{Explaining the differences in tax capacity}

We have shown that total direct tax revenue divided by the population was persistently higher in the southern zone of Mozambique than in the other two zones (north and centre). Our main argument is that the differences in the capacity of the state to extract taxes (and the effort put into it) derive mainly from the distinct local labour policies and practices.

However, in order to explain the differences in tax capacity between the three zones it is important to consider the factors that have conventionally been associated with the ability of the state to collect taxes, also termed "tax handles". We follow Stotsky and WoldeMariam, ${ }^{90}$ Mkandawire, ${ }^{9 \mathrm{I}}$ Feger and Asafu-Adjaye, ${ }^{92}$ and others in assessing quantifiable characteristics of the population and the economy, such as the dependency ratio (number of people aged zero to fifteen and above sixty-five, divided by the total population), population density (population per square kilometre), urbanization (urban population as a proportion of the total population), the ratio of Europeans to total population, the share of the population employed in agriculture, and the presence of an important port..$^{93}$

The statistical yearbooks of Mozambique allow us to gather information concerning these characteristics at a district level. Table 2 assembles the above variables, and displays the mean values over the early (1930 to 1949) and late (I950 to 1973) colonial period for each of the three zones. For a more encompassing overview, Appendix $\mathrm{C}$ displays the mean values for each

89. "Inspecção superior dos negocios indígenas".

90. Janet Gale Stotsky and Asegedech WoldeMariam, "Tax Effort in Sub-Saharan Africa”, IMF Working Paper 97/107 (1997), pp. I-57.

91. Mkandawire, "On Tax Efforts", explores the difference between tax share and tax effort. Tax share is a standard measure of the share of tax in GDP, while tax effort is the relationship between actual and potential levels of taxation.

92. Feger and Asafu-Adjaye, "Tax Effort Performance".

93. Income is one of the most important variables that explain fiscal capacity in the literature, but it is not possible for us to assess empirically the differences in income or in wages between the zones. 
Table 2. Determinants of tax capacity by zone.

\begin{tabular}{|c|c|c|c|c|c|c|}
\hline & & & & $\mathrm{re}^{*}$ & & \\
\hline & $\begin{array}{c}1930- \\
1949\end{array}$ & $\begin{array}{c}1950- \\
1973\end{array}$ & $\begin{array}{c}1930- \\
1949\end{array}$ & $\begin{array}{c}1950- \\
1973\end{array}$ & $\begin{array}{c}1930- \\
1949\end{array}$ & $\begin{array}{c}1950- \\
1973\end{array}$ \\
\hline $\begin{array}{l}\text { Direct taxes per } \\
\text { capita, deflated }\end{array}$ & 72.03 & 146.82 & 36.20 & 66.45 & 35.09 & 38.54 \\
\hline $\begin{array}{l}\text { Population density } \\
\left(\text { per } \mathrm{km}^{2}\right) \\
\text { Urbanization }\end{array}$ & 8.78 & 16.41 & 5.32 & 8.43 & 7.46 & 9.40 \\
\hline$(\text { year 1970) })^{94}$ & 0.06 & 0.06 & 0.02 & 0.02 & 0.01 & 0.01 \\
\hline Dependency ratio & 0.75 & 0.75 & 0.97 & 0.92 & 0.82 & 0.83 \\
\hline $\begin{array}{l}\text { Proportion of } \\
\text { whites (1960) }\end{array}$ & 0.04 & 0.04 & 0.01 & 0.01 & 0.00 & 0.00 \\
\hline Agricultural share & 0.54 & 0.56 & 0.71 & 0.72 & 0.90 & 0.87 \\
\hline Important port & Yes & Yes & Yes & Yes & No & No \\
\hline Capital city & Yes & Yes & No & No & No & No \\
\hline $\begin{array}{l}\text { Migrants per } 1,000 \\
\text { inhabitants }\end{array}$ & 39.74 & 40.32 & 0.00 & 0.00 & 0.00 & 0.00 \\
\hline
\end{tabular}

* Data on Manica e Sofala as from I943.

Source: Repartição Central de Estatística Geral, Anuários Estatísticos.

district per decade. Our aim is to describe the differences between the three zones with regard to the "tax handles" that the literature has identified.

The age structure of the population (represented by the dependency ratio) might influence tax capacity because only the economically active population pays taxes, whereas our per capita direct tax variable includes the whole population in the denominator. A lower dependency ratio would mean that there are more people to be taxed in the population and fewer dependent people. Here the south as a region displays the lowest dependency ratio and thus better conditions for raising taxes. However, the north (with the lowest direct tax levels) displays lower dependency ratios than the centre.

A dense population has been claimed to facilitate tax collection. It allows tax administrators to exercise control over a larger number of people in a given area. In our case, the coastal districts have a higher population density than those inland. Tete and Niassa, the only landlocked districts, have the lowest density of population. This is probably due to the high migration to the neighbouring British colonies, Northern and Southern Rhodesia, which attracted labour by paying higher wages. ${ }^{95}$ The districts of Lourenço 
Marques (south), Moçambique (north), and Zambezia (centre) - in that order - are the most densely populated. As a region, the south has the highest population density, the centre the lowest.

Urbanization influences tax capacity in a similar vein as population density. Herbst holds that in African colonies the government often limited its power to the urban centres, where the majority of colonists resided, and ignored the peripheral areas. ${ }^{96}$ Since state capacity is closely linked to tax capacity, urbanization will probably enhance tax revenue per capita. The most urbanized zone in colonial Mozambique was the south, given that it includes the capital city of Lourenço Marques. The north had the lowest urbanization rate; none of the larger cities was located there. Urbanization thus clearly seems to affect tax capacity. Relatedly, centres of trade activity, such as important ports, can generate cash flows that facilitate the collection of monetary taxes. According to Mozambique's statistical yearbooks, the most important ports were Lourenço Marques in the south and Beira in the centre.

Furthermore, the number of Europeans as a proportion of a district's total population is a potential determinant of tax revenue according to Amin's theory, which holds that in settler economies the native population was pushed into wage labour by the levying of indigenous taxes. The European population itself was mostly exempted from paying direct taxes. The number of Europeans as a proportion of total population was lowest in the peasant-based north and highest in the south (mainly driven by Lourenço Marques), which contains the capital city and European plantation farms, especially from the i 940 s. As already mentioned, European presence was a promoter of indigenous tax extraction.

A large share of the working population engaged in agriculture has also been claimed to have a negative impact on the tax capacity of the state because it includes subsistence farmers, who have difficulty in paying taxes in cash. Here, the north had the largest rate of agricultural employment, as we would expect, with ninety per cent of the working population engaged in this sector. We have already argued that the poor peasant-based north offered the worst conditions to extract taxes. Instead, as mentioned above, the south was home to large numbers of men employed in mining and possibly in services in the capital, which provided the state with more opportunities to collect direct taxes.

We also include in Table 2 the migrants-per-thousand-inhabitants variable. It takes the value zero for the north and the centre, since emigration was illegal there (and thus, only recorded as "from an unknown district"), and around forty per thousand for the south. For our argumentation, the large temporary migration to South Africa and to a lesser extent to Southern Rhodesia is very important in explaining the differences in tax capacity. 
Furthermore, we know from the literature that especially in the centre of the colony, where the concessionary companies operated, and also in the settler-dominated areas of the south, forced labour was common practice. However, it is unfortunately impossible to quantify forced labour in a consistent manner on an annual basis, since numbers of people recruited by force do not appear separately in the labour statistics and we found only poor and scattered information in classified reports or correspondence. Even if we could find approximate numbers of labourers employed in public works and on the colony's plantations, we would not be able to have this information per district.

In this section, we empirically showed the persistence of the unequal tax contribution of the three zones. We also analysed the differences between the regions with respect to geographic, demographic, and economic characteristics that are generally acknowledged to influence tax capacity. Variables affecting or capturing labour practices (Europeans as a proportion of the population, engagement in agriculture, urbanization, and emigration) clearly affected tax capacity. The question why the Portuguese administration failed to unify the fiscal and labour systems will be discussed below.

\section{COLONIAL STATE FORMATION WITHOUT INTEGRATION}

Why did Portugal fail to unify the three zones? First, the initial conditions, including geography as well as socio-economic and political institutions, played a crucial role in shaping different tax and labour patterns. Exogenous shocks, such as the discovery of gold in Transvaal, intensified migration streams from the south of Mozambique to the mines and further disconnected this area from the rest of the territory.

Second, Portugal was an economically disadvantaged imperial power compared with Britain or France. From early colonization up to the Depression (I930s), both Portugal and its African territories performed poorly in terms of budget balance. In order to limit the deficit and public expenses on colonial administration, the military, and infrastructure, the metropole either relied on concession companies and local chiefs or passed budget-tightening measures and stopped providing loans to the colonies. ${ }^{97}$ In a way, following the example of Britain, Portugal relied on a system of indirect colonial rule, for pragmatic and economic reasons rather than for ideological purposes. Also, under Salazar's New State regime the metropole adopted restrictive fiscal policies that did not permit substantial public investment in the local development of the colonies. On the one hand, under the authoritarian regime Portugal aimed to exercise tight control over

97. Kleoniki Alexopoulou, "Metropolitan Vision under Question: Fiscal Policies and Practices in Portuguese Africa, I850s-1970" (unpublished chapter, PhD dissertation, Wageningen University, 2017). 
its colonies - for example, by ending the concessions of companies. On the other hand, Mozambique's colonial government continued delegating administrative tasks such as tax collection to native authorities, while smaller companies took over agriculture and infrastructure development projects. The colonial state was incapable of fully controlling the implementation of those activities, since budget problems forced it to rely on various non-state actors. The limited degree of centralization, despite the repressive character of the state, severely hampered the unification of the colony.

Overall, Portuguese colonial policies and practices were responses to the dynamics already in place in the region of Mozambique, rather than proactive strategies to build solid fiscal and labour institutions in the colony. Eventually, this led to state formation without integration. There are, however, two points that Portuguese colonial rule could have altered regarding its fiscal and labour policies in order to reduce socio-economic inequality in the territory, but it chose not to make that effort.

First, from the I930s onwards, during Salazar's era, Portugal did not comply with the international labour standards of that period. It did not ratify the ILO agreements and did not end forced labour schemes until the I960s, which undoubtedly harmed its "legitimization" as a colonial power ${ }^{9}$ and drove the central and the northern zones of Mozambique into impoverishment and lack of monetization. Second, the Portuguese colonial state did not attempt to redistribute public income in favour of the rural areas, and especially the north of Mozambique, to diminish inequality between the zones. It is known from quantitative evidence that in the early colonial era most of the tax revenue was invested in security and administration, while in the late colonial era (after 1940) infrastructure investments took off, however almost exclusively in the cities and ports of the central and southern zone, such as Lourenço Marques and Beira. ${ }^{99}$ This way, Portuguese colonial rule contributed to the further widening of the gap between Mozambique's north and south.

\section{CONCLUSIONS}

We have shown that in terms of taxation and labour practices Mozambique consisted of three different zones (north, centre, and south), which fit Samir Amin's categorization into "regions of colonial influence". Different

98. For instance, repressive policies and practices such as forced labour were used by other colonial powers or by the state and companies in South Africa as an argument to deny Mozambique access to credit markets. See Vail and White, “Tawani, Machambero!", p. 242.

99. Kleoniki Alexopoulou, "Regressive Redistribution and Infrastructure Development in Portuguese Africa (I890s-1970s)" (unpublished chapter, $\mathrm{PhD}$ dissertation, Wageningen University, 2017). 
labour systems have operated in the three geographic zones since early colonization, and these differences were maintained and exploited under colonial rule, also for the purpose of tax collection.

The empirical analysis demonstrated that the south, which operated as a labour reserve for the mines of South Africa, had significantly higher tax capacity than the peasant and concession economies in the north and centre, and this pattern persisted over time. Variables affecting or capturing labour practices (the share of Europeans in the population, engagement in agriculture, urbanization, and migration) were shown to be correlated with tax capacity, as expected.

We argued that the causes of the lack of integration in the process of colonial state formation in Mozambique are related both to local socioeconomic conditions, including labour practices, and to metropolitan identity (Portugal as a weak imperial power in economic terms). Colonial rule did not considerably alter the conditions underlying fiscal inequality between the three zones. Instead, the colonial policies and practices concerning administration, taxation, and most importantly labour, reinforced the regional differences. Over the early decades (I890s-I930s), the colonial state delegated administrative tasks to concession companies in central and northern Mozambique and until as late as 1960 used forced labour schemes, while in southern Mozambique it institutionalized labour migration to the mines in South Africa and taxed migrant incomes. Either by extracting revenue or saving expenditure, Portuguese rule exploited the existing patterns and failed to improve labour conditions for the indigenous people and to regionally redistribute public income.

Nowadays, Mozambique is considered a failed state. Our research has important implications for the understanding of state formation and fiscal capacity-building in colonial and even post-colonial Africa, given that fiscal systems are highly path dependent and integration is a crucial component of state stabilization. For instance, in the post-colonial era migrant workers' wages still contributed significantly to the Mozambican economy.

\section{TRANSLATED ABSTRACTS \\ FRENCH - GERMAN - SPANISH}

Kleoniki Alexopoulou et Dácil Juif. Formation d'un État colonial sans intégration: la capacité fiscale et les régimes de travail an Mozambique portugais (I 890-1970).

Samir Amin (1972) a divisé le continent africain en trois "macro-régions d'influence coloniale" dotées de systèmes socio-économiques et de pratiques de travail distincts: l'Afrique du commerce colonial ou de l'économie paysanne, l'Afrique des sociétés propriétaires de concessions et l'Afrique des réserves de main d'œuvre. Nous soutenons que le Mozambique a englobé toutes les trois "macro-régions" différentes dans une seule colonie. Nous reconstruisons les recettes publiques (impôts directs/ 
indirects) prélevées au niveau du district entre 1930 et 1973 , et nous relevons des différences persistantes dans la "capacité fiscale" des trois régions durant toute la période coloniale. Les systèmes fiscaux, selon nous, se sont développés en réponse à des conditions géographiques et économiques locales, et particulièrement à des pratiques de travail. La règle coloniale portugaise s'est ajustée à et a encouragé certaines pratiques de travail, telles que la migration et le travail forcé, afin d'optimiser les revenus. Le point auquel le manque d'intégration a joué un rôle dans l'État postcolonial et l'échec fiscal devraient faire l'objet d'études plus approfondies.

\section{Traduction: Christine Plard}

Kleoniki Alexopoulou und Dácil Juif. Koloniale Staatsformierung obne Integration: Stenerkraft und Arbeitsregime im portugiesisch regierten Mosambik (I89oer bis I97oer Jabre).

Samir Amin (1972) hat den afrikanischen Kontinent in drei "Makroregionen kolonialen Einflusses” mit je eigenen sozioökonomischen System und Arbeitspraktiken unterteilt: das Afrika des Kolonialhandels oder der kleinbäuerlichen Wirtschaft, das der über Konzessionen verfügenden Konzerne und das der Arbeitskräftereserven. Wir vertreten die These, dass Mosambik alle drei “Makroregionen” in einer einzigen Kolonie verband. Wir rekonstruieren die Einnahmen aus direkten und indirekten Steuern, die dem Staat zwischen I 930 und 1973 auf der Bezirksebene entstanden sind, und konstatieren, dass es während der Kolonialzeit anhaltende Differenzen in der "Steuerkraft" der drei Regionen gab. Die Steuersysteme entwickelten sich, so argumentieren wir, in Reaktion auf die lokal gegebenen geografischen und wirtschaftlichen Bedingungen, insbesondere in Reaktion auf die jeweiligen Arbeitspraktiken. Die portugiesische Kolonialherrschaft passte sich Praktiken wie der Migration und der Zwangsarbeit an und förderte sie, um die eigenen Einnahmen zu maximieren. Inwiefern der Mangel an Integration für den postkolonialen Staat und dessen fiskalisches Versagen eine Rolle gespielt hat, sollte noch näher untersucht werden.

\section{Übersetzung: Max Henninger}

Kleoniki Alexopoulou y Dácil Juif. La formación de un estado colonial sin integración: capacidad impositiva y regímenes laborales en el Mozambique Portugués (I890-I970).

En 1972 Samir Amin dividió el continente africano en tres “macroregiones de influencia colonial” con unos sistemas socioeconómicos y unas prácticas laborales distintas: el África del comercio colonial o de la economía campesina, el África de las empresas propietarias de concesiones, y el África de las reservas de trabajo. En el artículo consideramos que Mozambique abarca esos tres tipos diferentes de macroregiones en una sola colonia. En él realizamos una reconstrucción de los ingresos (tanto de los impuestos directos como de los indirectos) recaudados por el gobierno a nivel regional entre 1930 y 1973 . Encontramos diferencias continuadas en la "capacidad impositiva" de las tres regiones a lo largo del periodo colonial. Consideramos que el sistema de impuestos se desarrolló en respuesta a las condiciones geográficas y 
económicas existentes a nivel local, particularmente en lo que se refiere a las prácticas laborales. La legislación colonial portuguesa adaptó y promovió unas determinadas prácticas de trabajo tales como la migración y el trabajo forzado para conseguir una maximización de los ingresos impositivos. Las implicaciones de esta falta de integración jugaron un papel destacado en el estado post-colonial y en su quiebra fiscal; un aspecto que deberá ser estudiado con mayor profundidad.

Traducción: Vicent Sanz Rozalén 
APPENDIX A: NUMBER OF MIGRANTS TO SOUTH AFRICA BY DISTRICT OF ORIGIN

\begin{tabular}{|c|c|c|c|c|c|c|c|c|c|}
\hline \multirow[b]{2}{*}{ Year } & \multicolumn{5}{|c|}{ Total numbers } & \multicolumn{4}{|c|}{ Per 1,000 inhabitants } \\
\hline & $\begin{array}{l}\text { Lourenço } \\
\text { Marques }\end{array}$ & Gaza & Inhambane & $\begin{array}{l}\text { Unknown } \\
\text { district }\end{array}$ & Total & $\begin{array}{l}\text { Lourenço } \\
\text { Marques }\end{array}$ & Gaza & Inhambane & $\begin{array}{l}\text { Unknown } \\
\text { district }\end{array}$ \\
\hline 1929 & 2,915 & 16,265 & 19,629 & 8,645 & 47,454 & 22.1 & 50.2 & 73.0 & $\mathrm{n} / \mathrm{d}$ \\
\hline 1930 & 3,089 & 16,270 & 18,329 & 13,345 & 51,033 & & 54.4 & 55.7 & $\mathrm{n} / \mathrm{d}$ \\
\hline 1931 & 3,135 & 13,446 & 15,183 & 18,279 & 50,043 & 5.2 & 36.8 & 46.2 & $\mathrm{n} / \mathrm{d}$ \\
\hline 1932 & 2,420 & 10,390 & 10,936 & 12,210 & 35,956 & 12.4 & 19.8 & 31.1 & $\mathrm{n} / \mathrm{d}$ \\
\hline 1933 & 3,697 & 10,604 & 12,173 & 13,294 & 39,768 & 20.5 & 22.3 & 40.4 & $\mathrm{n} / \mathrm{d}$ \\
\hline 1934 & 3,690 & 15,174 & 14,731 & 15,358 & 48,953 & 19.8 & 37.4 & 44.8 & $\mathrm{n} / \mathrm{d}$ \\
\hline 1935 & 4,199 & 17,889 & 14,701 & 18,333 & 55,122 & 21.8 & 68.8 & 44.6 & $\mathrm{n} / \mathrm{d}$ \\
\hline 1936 & 4,358 & 21,379 & 21,852 & 18,132 & 65,721 & 24.2 & 58.4 & 66.3 & $\mathrm{n} / \mathrm{d}$ \\
\hline 1937 & 3,840 & 20,754 & 20,983 & 14,463 & 60,040 & 20.7 & 56.7 & 63.6 & $\mathrm{n} / \mathrm{d}$ \\
\hline 1938 & 4,928 & 25,504 & 25,946 & 12,388 & 68,766 & 23.1 & 69.7 & 78.7 & $\mathrm{n} / \mathrm{d}$ \\
\hline 1939 & 5,501 & 19,451 & 27,714 & 11,400 & 64,066 & 29.7 & 71.8 & 84.0 & $\mathrm{n} / \mathrm{d}$ \\
\hline 1940 & 6,019 & 22,584 & 24,096 & 10,743 & 63,442 & 41.4 & 35.5 & 54.9 & $\mathrm{n} / \mathrm{d}$ \\
\hline 1941 & 5,485 & 29,118 & 26,840 & 9,112 & 70,555 & 29.6 & 45.8 & 57.9 & $\mathrm{n} / \mathrm{d}$ \\
\hline 1942 & 5,763 & 26,540 & 28,356 & 5,510 & 66,169 & 23.6 & 41.9 & 61.1 & $\mathrm{n} / \mathrm{d}$ \\
\hline 1943 & 6,233 & 33,873 & 29,386 & 6,647 & 76,139 & 25.5 & 53.5 & 63.3 & $\mathrm{n} / \mathrm{d}$ \\
\hline 1944 & 5,238 & 28,770 & 28,954 & 7,131 & 70,093 & 21.6 & 45.4 & 62.4 & $\mathrm{n} / \mathrm{d}$ \\
\hline 1945 & 4,394 & 31,114 & 27,614 & 7,621 & 70,743 & 20.9 & 49.1 & 59.5 & $\mathrm{n} / \mathrm{d}$ \\
\hline 1946 & 4,936 & 29,695 & 27,003 & 8,000 & 69,634 & 20.3 & 52.6 & 56.2 & $\mathrm{n} / \mathrm{d}$ \\
\hline 1947 & 3,498 & 31,069 & 26,814 & 9,777 & 71,158 & 14.4 & 54.9 & 55.9 & $\mathrm{n} / \mathrm{d}$ \\
\hline 1948 & 4,149 & 26,943 & 29,473 & & 60,565 & 16.9 & 47.7 & 61.3 & $\mathrm{n} / \mathrm{d}$ \\
\hline 1949 & 4,703 & 30,078 & 31,985 & & 66,766 & 19.2 & 53.3 & 66.6 & $\mathrm{n} / \mathrm{d}$ \\
\hline 1950 & 4,963 & 27,888 & 27,748 & & 60,609 & 20.3 & 51.3 & 57.7 & $\mathrm{n} / \mathrm{d}$ \\
\hline
\end{tabular}

Source: Repartição Central de Estatística Geral, Anuários Estatísticos. 
APPENDIX B: MIGRANTS'SALARIES (CONSTANT 1954 ESCUDOS)

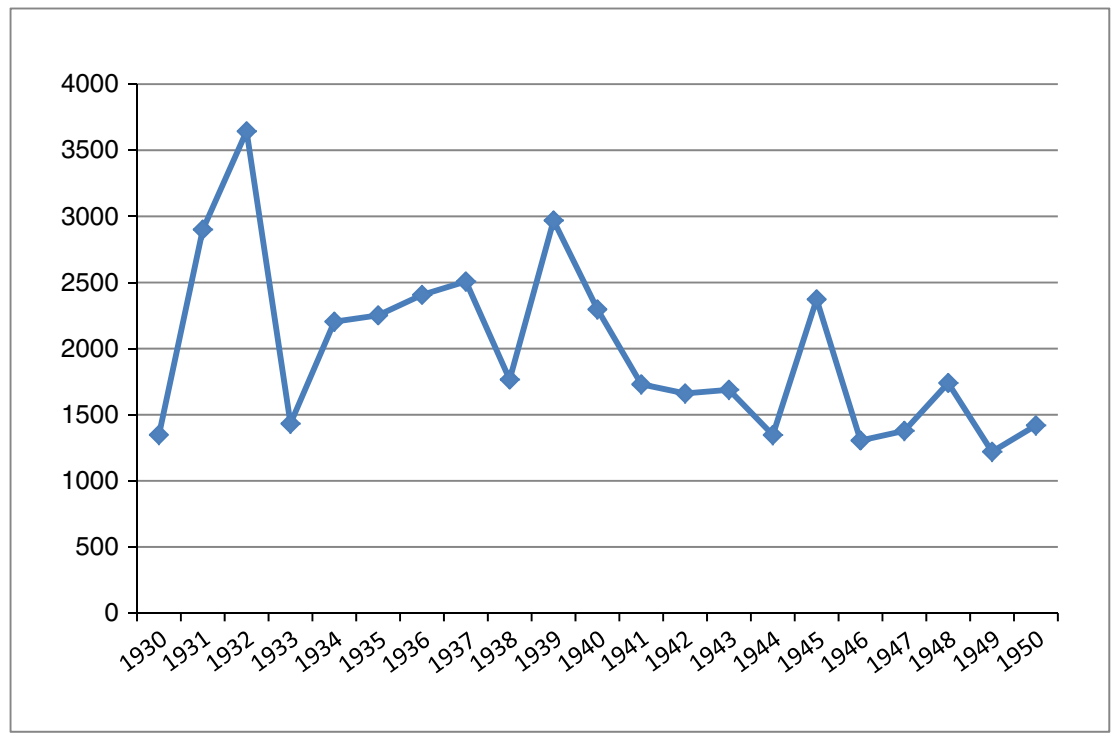

Source: Repartição Central de Estatística Geral, Anuários Estatísticos; price deflator: Valério, Estatísticas históricas portuguesas. 
APPENDIX C: MEAN VARIABLES BY DISTRICT AND DECADE

\begin{tabular}{|c|c|c|c|c|c|c|c|c|c|c|c|}
\hline Zone & District & Decade & $\begin{array}{l}\text { Dependency } \\
\text { ratio }\end{array}$ & $\begin{array}{l}\text { Proportion } \\
\text { of whites }\end{array}$ & $\begin{array}{l}\text { Agricultural } \\
\text { share }\end{array}$ & $\begin{array}{c}\text { Population } \\
\text { density }\end{array}$ & Urbanization & $\begin{array}{l}\text { Capital } \\
\text { city }\end{array}$ & $\begin{array}{l}\text { Important } \\
\text { port }\end{array}$ & $\begin{array}{l}\text { Migrants } \\
\text { per'000 }\end{array}$ & $\begin{array}{l}\text { Direct taxes per } \\
\text { capita (deflated) }\end{array}$ \\
\hline \multirow[t]{15}{*}{ Centre } & \multirow{5}{*}{$\begin{array}{l}\text { Manica e } \\
\text { Sofala }\end{array}$} & 1930 & 0.89 & 0.025 & 0.64 & 3.31 & 0.049 & 0 & 0 & 0.00 & \\
\hline & & 1940 & 0.89 & 0.025 & 0.64 & 3.79 & 0.049 & 0 & 1 & 0.00 & 116.17 \\
\hline & & 1950 & 0.84 & 0.025 & 0.64 & 5.01 & 0.049 & 0 & 1 & 0.00 & 89.80 \\
\hline & & 1960 & 0.85 & 0.025 & 0.62 & 6.31 & 0.049 & 0 & 1 & $\mathrm{n} / \mathrm{d}$ & 129.53 \\
\hline & & 1970 & 0.97 & 0.025 & 0.62 & 7.67 & 0.049 & 0 & 1 & $\mathrm{n} / \mathrm{d}$ & 168.81 \\
\hline & \multirow[t]{5}{*}{ Tete } & 1930 & 1.09 & 0.005 & 0.68 & 3.34 & 0.009 & 0 & 0 & 0.00 & 28.29 \\
\hline & & 1940 & 1.09 & 0.005 & 0.68 & 4.13 & 0.009 & 0 & 0 & 0.00 & 24.76 \\
\hline & & 1950 & 0.88 & 0.005 & 0.68 & 4.50 & 0.009 & 0 & 0 & 0.00 & 17.75 \\
\hline & & 1960 & 0.98 & 0.005 & 0.68 & 4.70 & 0.009 & 0 & 0 & $\mathrm{n} / \mathrm{d}$ & 15.37 \\
\hline & & 1970 & 0.99 & 0.005 & 0.78 & 5.08 & 0.009 & 0 & 0 & $\mathrm{n} / \mathrm{d}$ & 29.61 \\
\hline & \multirow[t]{5}{*}{ Zambezia } & 1930 & 0.95 & 0.005 & 0.81 & 7.94 & 0.007 & 0 & 0 & 0.00 & 36.09 \\
\hline & & 1940 & 0.95 & 0.005 & 0.81 & 9.39 & 0.007 & 0 & 0 & 0.00 & 40.91 \\
\hline & & 1950 & 0.85 & 0.005 & 0.81 & 11.89 & 0.007 & 0 & 0 & 0.00 & 37.91 \\
\hline & & 1960 & 0.90 & 0.005 & 0.83 & 14.03 & 0.007 & 0 & 0 & $\mathrm{n} / \mathrm{d}$ & 40.82 \\
\hline & & 1970 & 1.00 & 0.005 & 0.83 & 16.71 & 0.007 & 0 & 0 & $\mathrm{n} / \mathrm{d}$ & 57.25 \\
\hline \multirow[t]{14}{*}{ North } & \multirow{5}{*}{$\begin{array}{l}\text { Cabo } \\
\text { Delgado }\end{array}$} & 1930 & 0.72 & 0.003 & 0.92 & 5.22 & 0.012 & 0 & 0 & 0.00 & 33.56 \\
\hline & & 1940 & 0.72 & 0.003 & 0.92 & 6.43 & 0.012 & 0 & 0 & 0.00 & 25.27 \\
\hline & & 1950 & 0.68 & 0.003 & 0.92 & 7.02 & 0.012 & 0 & 0 & 0.00 & 21.67 \\
\hline & & 1960 & 0.74 & 0.003 & 0.85 & 7.58 & 0.012 & 0 & 0 & $\mathrm{n} / \mathrm{d}$ & 29.96 \\
\hline & & 1970 & 0.85 & 0.003 & 0.85 & 7.61 & 0.012 & 0 & 0 & $\mathrm{n} / \mathrm{d}$ & 34.72 \\
\hline & \multirow{5}{*}{ Mozambique } & 1930 & 0.75 & 0.006 & 0.89 & 13.92 & 0.016 & 0 & 0 & 0.00 & 48.72 \\
\hline & & 1940 & 0.75 & 0.006 & 0.89 & 16.00 & 0.016 & 0 & 0 & 0.00 & 33.50 \\
\hline & & 1950 & 0.69 & 0.006 & 0.89 & 16.87 & 0.016 & 0 & 0 & 0.00 & 32.57 \\
\hline & & 1960 & 0.77 & 0.006 & 0.85 & 18.51 & 0.016 & 0 & 0 & $\mathrm{n} / \mathrm{d}$ & 51.98 \\
\hline & & 1970 & 0.81 & 0.006 & 0.85 & 20.95 & 0.016 & 0 & 0 & $\mathrm{n} / \mathrm{d}$ & 64.62 \\
\hline & \multirow[t]{4}{*}{ Niassa } & 1930 & 0.98 & 0.003 & 0.89 & 1.45 & 0.011 & 0 & 0 & 0.00 & 14.02 \\
\hline & & 1940 & 0.98 & 0.003 & 0.89 & 1.76 & 0.011 & 0 & 0 & 0.00 & 8.94 \\
\hline & & 1950 & 0.98 & 0.003 & 0.89 & 1.79 & 0.011 & 0 & 0 & 0.00 & 13.01 \\
\hline & & 1960 & 0.97 & 0.003 & 0.88 & 1.96 & 0.011 & 0 & 0 & $\mathrm{n} / \mathrm{d}$ & 21.97 \\
\hline
\end{tabular}


(Continued)

\begin{tabular}{|c|c|c|c|c|c|c|c|c|c|c|c|}
\hline Zone & District & Decade & $\begin{array}{l}\text { Dependency } \\
\text { ratio }\end{array}$ & $\begin{array}{l}\text { Proportion } \\
\text { of whites }\end{array}$ & $\begin{array}{l}\text { Agricultural } \\
\text { share }\end{array}$ & $\begin{array}{c}\text { Population } \\
\text { density }\end{array}$ & Urbanization & $\begin{array}{l}\text { Capital } \\
\text { city }\end{array}$ & $\begin{array}{l}\text { Important } \\
\text { port }\end{array}$ & $\begin{array}{l}\text { Migrants } \\
\text { per'000 }\end{array}$ & $\begin{array}{l}\text { Direct taxes per } \\
\text { capita (deflated) }\end{array}$ \\
\hline & & 1970 & 1.01 & 0.003 & 0.88 & 2.28 & 0.011 & 0 & 0 & $\mathrm{n} / \mathrm{d}$ & 28.29 \\
\hline \multirow[t]{15}{*}{ South } & \multirow[t]{5}{*}{ Gaza } & 1930 & 0.83 & 0.011 & 0.61 & 5.11 & 0.028 & 0 & 0 & 42.19 & 35.12 \\
\hline & & 1940 & 0.83 & 0.011 & 0.61 & 7.43 & 0.028 & 0 & 0 & 47.22 & 43.64 \\
\hline & & 1950 & 0.77 & 0.011 & 0.61 & 7.31 & 0.028 & 0 & 0 & 51.27 & 43.53 \\
\hline & & 1960 & 0.78 & 0.011 & 0.61 & 8.48 & 0.028 & 0 & 0 & $\mathrm{n} / \mathrm{d}$ & 38.89 \\
\hline & & 1970 & 0.87 & 0.011 & 0.61 & 9.47 & 0.028 & 0 & 0 & $\mathrm{n} / \mathrm{d}$ & 43.68 \\
\hline & \multirow[t]{5}{*}{ Inhambane } & 1930 & 0.87 & 0.003 & 0.70 & 5.36 & 0.010 & 0 & 0 & 50.64 & 36.63 \\
\hline & & 1940 & 0.87 & 0.003 & 0.70 & 7.19 & 0.010 & 0 & 0 & 58.88 & 50.58 \\
\hline & & 1950 & 0.68 & 0.003 & 0.70 & 8.56 & 0.010 & 0 & 0 & 52.38 & 33.03 \\
\hline & & 1960 & 0.75 & 0.003 & 0.77 & 9.40 & 0.010 & 0 & 0 & $\mathrm{n} / \mathrm{d}$ & 47.78 \\
\hline & & 1970 & 0.81 & 0.003 & 0.77 & 11.15 & 0.010 & 0 & 0 & $\mathrm{n} / \mathrm{d}$ & 46.39 \\
\hline & \multirow{5}{*}{$\begin{array}{l}\text { Lourenço } \\
\text { Marques }\end{array}$} & 1930 & 0.54 & 0.110 & 0.31 & 12.08 & 0.153 & 1 & 1 & 19.12 & 176.02 \\
\hline & & 1940 & 0.54 & 0.110 & 0.31 & 15.50 & 0.153 & 1 & 1 & 20.36 & 222.43 \\
\hline & & 1950 & 0.56 & 0.110 & 0.31 & 20.41 & 0.153 & 1 & 1 & 17.32 & 248.83 \\
\hline & & 1960 & 0.68 & 0.110 & 0.33 & 29.71 & 0.153 & 1 & 1 & $\mathrm{n} / \mathrm{d}$ & 472.81 \\
\hline & & 1970 & 0.82 & 0.110 & 0.33 & 43.18 & 0.153 & 1 & 1 & $\mathrm{n} / \mathrm{d}$ & 764.96 \\
\hline
\end{tabular}

Source: Repartição Central de Estatística Geral, Anuários Estatísticos. 